$$
\begin{gathered}
\text { Colloquia Litteraria } \\
\text { UKSW } \\
22012
\end{gathered}
$$

\title{
POLIFONIA POWIEŚCI DOSTOJEWSKIEGO A ZAGADNIENIE WIELOGLOSOWOŚCI POEZJI NORWIDA
}

Dokonane przez Bachtina odkrycie polifonii powieści Dostojewskiego $^{1}$ stało się jednym z najbardziej ważkich i wpływowych twierdzeń literaturoznawczych XX wieku. Choć już przed publikacją Problemów twórczości Dostojewskiego i po niej pojawiły się prace uzupełniające i polemiczne wobec twierdzeń rosyjskiego uczonego ${ }^{2}$, to jednak właśnie jego tezy najgłębiej ugruntowały się w światowej humanistyce.

Bachtin wiązał nowatorskie rozwiązanie literackie, zastosowane przez Dostojewskiego, z jego głębokim przekonaniem o należnym każdemu człowiekowi szacunku, którego podstawowym przejawem jest wolność wypowiadania się. Ten rodzaj ujęcia problemu (choć nie-

1 Na temat gruntownej analizy pojęcia polifonii Bachtina-Dostojewskiego zob. Halina Brzoza, Polifonia i wielostylowość czy przewrotna spójność rozpadu? Bliżej Bachtinowskiej koncepcji estetyki Dostojewskiego, w: taż, Dostojewski. Myśl a forma, Łódź 1984.

2 Por. oryginalne Bachtinowskie omówienie literatury przedmiotu, oscylującej wokół problemu dialogowości Dostojewskiego: Michał Bachtin, Problemy poetyki Dostojewskiego, tłum. W. Grajewski, w: Ja - Inny. Wokót Bachtina. Antologia, red. D. Ulicka, t. 1., Kraków 2009, s. $153-180$.

3 W tym kontekście Bachtin posługuje się określeniem, które zostało przetłumaczone na język polski jako 'personalizm' (Por. „Świat Dostojewskiego jest dogłębnie personalistyczny. Wszelką myśl postrzega on i przedstawia jako pozycję osoby.” (dz. cyt., s. 155). Jednak wydaje się, że choć w oryginale w odpowiednim miejscu widnieje słowo do złudzenia podobne ‘персоналистичен', to jednak w języku rosyjskim może ono oznaczać nie tylko „personalistyczny”, ale też - „osobowy”, „dotyczący osoby”. Рor. ПЕРСОНАЛьНЫЙ, ая, ое [латин. personalis] (книжн. офиц.). 1. Прил. к персонал (устар.). П. состав. 2. Касающийся лично данного 
wyrażony przez Bachtina zupełnie wprost) staje się szczególnie frapujący na tle sytuacji wydawniczej w carskiej Rosji i Rosji Radzieckiej.

Wartość samodzielnych i nie łączących się ze sobą głosów i świadomości, prawdziwa polifonia pełnowartościowych głosów, stanowi, w istocie, podstawową właściwość powieści Dostojewskiego. W jego utworach mamy do czynienia nie z losami i życiem bohaterów w jednolitym obiektywnym świecie, ukazanym w świetle jednej autorskiej świadomości, lecz właśnie z mnogością równoprawnych świadomości i ich światów, które łączą się ze sobą, nie tracąc swojej odrębności, w jedność pewnego zdarzenia. Rzeczywiście, główni bohaterowie Dostojewskiego stanowią już w samym twórczym zamyśle artysty nie tylko przedmioty słowa autorskiego, ale również podmioty słowa własnego, bezpośrednio znaczącego. Słowo bohatera nie ogranicza się tutaj do zwykłych funkcji charakteryzacyjnych i fabularno-pragmatycznych, nie służy też autorowi jako wyraz jego własnej pozycji ideologicznej (jak to się dzieje, na przykład, u Byrona). Świadomość bohatera dana jest jako inna, cudza świadomość, a zarazem nie podlega uprzedmiotowieniu ani zamknięciu, nie staje się zwykłym przedmiotem świadomości autorskiej

W przytoczonym wyżej cytacie, wprowadzającym do lektury Problemów..., Bachtin wskazuje na kilka zasadniczych kwestii, charakteryzujących poetykę uprawianą przez Dostojewskiego. Są to (w pewnym koniecznym uproszczeniu): rozbicie jednolitej wizji świata autorskiego oraz zupełne usamodzielnienie się głosów bohaterów powieści i opowiadań rosyjskiego pisarza.

Dopatrywano się rozmaitych źródeł tego nowatorskiego rozwiązania z dziedziny poetyki dzieła literackiego. Przede wszystkim wskazywano na kryzys religijno-światopoglądowy, który przez szereg lat

человека. Персональное приглашение. Персональная ответственность. Персональная пенсия. || Исходящий от какого-н. отдельного лица, от каких-н. определенных лиц. Персональные жалобы. Персонально (нареч.) распорядится. (Tołkowyj stowar' russkogo jazyka, gławnaja redakcyja B. M. Wołnin, D. N. Uszakow, t. II, Moskwa 1939, s. 235).

4 Michał Bachtin, Problemy poetyki Dostojewskiego, dz. cyt., s. 154. 
przeżywał Dostojewski ${ }^{5}$. Drugim, alternatywnym nurtem badawczym stało się uruchomienie kontekstu prawosławnego nauczania o człowieku, ostatnio szczególnie akcentujące ,kardiocentryczną” (określenie Doroty Jewdokimow) ${ }^{6}$ antropologię Dostojewskiego. Wydaje się jednak, że oba zasadnicze nurty refleksji nad spuścizną autora Biesów, wypływające $\mathrm{z}$ rewelatorskich ustaleń Bachtina, należy - w miarę możliwości - brać pod uwagę w równym stopniu. Dopiero ich połączenie może rzucić więcej światła na źródła polifonicznego ukształtowania powieści Dostojewskiego, pozostającego w niewątpliwym związku z jego koncepcją „realizmu w wyższym sensie"7.

Jeśli idzie o wielogłosowość Norwida, w roku 1967 został opublikowany przełomowy szkic Michała Głowińskiego Wirtualny odbiorca w strukturze utworu poetyckiego, w którym - jak się wydaje - po raz pierwszy zaistniały przesłanki do mówienia o swego rodzaju wielogłosowości w poezji Norwida. Choć wspomniany artykuł był wielokrotnie przedrukowywany w kraju i miał kilka tłumaczeń na język niemie$\mathrm{cki}^{8}$, to jednak wątki poświęcone w nim autorowi Ostatniego despotyzmu zyskały szersze echo jedynie w środowisku norwidologicznym.

Kilka lat później (w roku 1972) Głowiński powrócił do zagadnienia szczególnego ukształtowania struktury liryków autora Vade-mecum w szkicu Norwidowska druga osoba. Tekst ten również wszedł do kanonu literaturoznawczej wiedzy o poecie, jednak pozostał raczej niezauważony przez literaturoznawców nie zajmujących się Norwidem.

Warto przyjrzeć się temu, w jaki sposób stopniowo ewoluowało myślenie Głowińskiego o Norwidzie. Początkowo badacz posłużył się tekstem poety jedynie w sposób instrumentalny - Ostatni despotyzm

\footnotetext{
5 Zob. Lew Szestow, Dostojewski i Nietzsche. Filozofia tragedii, tłum. C. Wodziński, Warszawa 1987. Bohdan Urbankowski, Dostojewski. Dramat humanizmów, Warszawa 1994.

6 Zob. Paul Evdokimov, Gogol i Dostojewski, czyli zstapienie do otchłani, thum. A. Kunka, Bydgoszcz 2002. Henryk Paprocki, Lew i mysz, czyli tajemnica człowieka. Esej o bohaterach Dostojewskiego, Białystok 1997. Dorota Jewdokimow, Człowiek przemieniony. Fiodor M. Dostojewski wobec tradycji Kościoła Wschodniego, Poznań 2009.

7 Fiodor M. Dostojewskij, Polnoje sobranije soczinienij w tridcati tomach, Leningrad 19721980, t. 27, s. 65.

8 Michał Głowiński, Style odbioru. Szkice o komunikacji literackiej, Kraków 1977, s. 251.
} 
miał być wyłącznie ilustracją jego tezy o potencjalnych napięciach w sferze komunikacji literackiej między twórcą a zakładanym przezeń wirtualnym odbiorca. Tekst Norwida stał się tu przykładem skrajnego przełamywania obowiązujących w XIX wieku konwencji poetyckich:

[XIX-wieczny odbiorca] wobec Ostatniego despotyzmu stawał bezradny, utwór ten musiał na nim sprawiać wrażenie pisanego hieroglifami, mimo że każde ze słów brane osobno było w pełni zrozumiałe.

\section{I trochę dalej:}

Ten fakt $[. .$.$] wynika zdialogowego charakteru wiersza i spra-$ wia, że jego 13-zgłoskowiec ma już niewiele wspólnego z klasycznymi postaciami tego tak silnie utrwalonego w polskiej tradycji metrum. Wynika z nastawienia na cudzą mowę, cow poezji w ogóle, a w poezji tej epoki w szczególności, stanowi rzadkość 9 .

Dystynktywną cechą poezji Norwida staje się zatem, w myśl Głowińskiego, jej „charakter dialogowy” i ,nastawienie na cudzą mowę”. Zjawiska te były dla polskiej poezji XIX wieku tak skrajnie nowe, że nie sposób było ich właściwie odczytać. Poezja wcześniejsza, poezja „wielkich romantyków” była domeną wyłącznie ekspresji osobowości podmiotu lirycznego. Odbiorca, jak dobrze nastrojony instrument muzyczny, miał pozwolić mu się ponieść, miał sekundować jego przeżyciom i podziwiać jego wrażliwość. Najważniejszą płaszczyzną porozumienia między piszącym a czytającym, umożliwiającą właściwą komunikację literacką, stawała się głęboka, „romantyczna” wrażliwość czytającego, domagająca się od piszącego eklektyzmu gatunkowo-rodzajowego, mogącego wyrazić więcej i lepiej. Norwid zachowywał się pod tym względem w sposób skrajnie odmienny. Jego mocno ugruntowana wrażliwość religijna w pełni respektowała całą gamę uczuć ludz-

9 Michał Głowiński, Wirtualny odbiorca $w$ strukturze utworu poetyckiego, w: tenże, Style odbioru, dz. cyt., s. 86 i 87. Podkr. moje - E. S. 
kich, ale wymagała od odbiorcy jeszcze czegoś więcej - towarzyszącego lekturze wysiłku intelektualnego ${ }^{10}$.

Innym źródłem Norwidowej dialogowości było (mówiąc nieco anachronicznie) jego nastawienie personalistyczne, polegające przede wszystkim na wyjątkowym szacunku do Innego. Pisze o tym Głowiński w późniejszym szkicu:

Osobliwość owej Norwidowskiej drugiej osoby można by tak określić: wszelkie rozmyślanie nie przebiega w samotności, wymaga partnera, którego obecność wpływać może na tok medytacji, podpowiadać taki czy inny wątek, partnera, który może być oponentem i reprezentować inne niż podmiot stanowisko, a więc tym bardziej oddziaływać na jego samookreślenie, na krystalizowanie się jego mniemań. Proces rozmyślań w poezji Norwida, a zwłaszcza w większości utworów z Vade-mecum, jest procesem zsocjologizowanym, nie ogranicza się do świadomości rozmyślającego bohatera, jest skierowany na zewnątrz - właśnie ku drugiej osobie ${ }^{11}$.

Przytoczone wyżej rozważania Głowińskiego w kilku punktach do złudzenia przypominają refleksje Bachtina, wypowiedziane na temat polifonii powieści Dostojewskiego. Zresztą to podobieństwo do refleksji rosyjskiego uczonego zauważa i sam Głowiński, pisząc w zakończeniu cytowanego szkicu o przydatności stosowania kategorii wypracowanych przez Bachtina do opisu poezji Norwida.

10 Ten aspekt poezji Norwida został wcześnie zauważony przez badaczy i mocno (może przesadnie mocno wyeksponowany). Chyba tu właśnie mają swoje źródło pełne przekory zdania Danuty Zamącińskiej: „«Norwid był pisarzem głęboko intelektualnym» - powiada Alicja Lisiecka. Za kim to zdanie powtarza? Mniej ważne, bo nie ma pracy o Norwidzie, która by tę formułę wyminęła, ale po co powtarza, skoro i przyjęta, i trafna opinia? Jeśli więc każdy interpretator uważa jednak za niezbędne jej przypomnienie i przytoczenie - mogę podejrzewać, że sprawa nie jest tak oczywista, że może mam do czynienia z metodą wmówienia, że intelektualny, bo właściwie nieintelektualny? A może formuła pozwala zachować tylko dobre samopoczucie uczonym czytelnikom poety? Jeśli przedmiot badań tak intelektualny, to podmiot badający jest intelektualny do potęgi?" (Danuta Zamącińska, Poznawanie poezji Norwida, w: taż, Stynne - nieznane. Wiersze późne Mickiewicza, Słowackiego, Norwida, Lublin 1985, s. 61).

11 Michał Głowiński, Norwidowa druga osoba, w: tenże, Prace wybrane, t. V, Intertekstualność, groteska, parabola. Szkice ogólne i interpretacje, red. R. Nycz, Kraków 2000, s. 342. 


\section{Dialogowość Norwida na tle wcześniejszej polskiej tradycji literackiej}

Dialogowość poezji Norwida stała się dość późnym odkryciem literaturoznawczym, choć jej waga pod względem historycznego rozwoju poezji polskiej wydaje się nie do przecenienia. Natomiast przyglądając się stosowanym przez poetę rozstrzygnięciom dialogowym na tle twórczości Fiodora Dostojewskiego, łatwo zbagatelizować wagę wprowadzonego przez Norwida novum poetyckiego. Dlatego też wydaje się, że w pełni uzasadnione pod względem metodologicznym będzie z konieczności bardzo skrótowe (i abstrahujące na chwilę od Dostojewskiego) przyjrzenie się poezji Norwida na tle wcześniejszej liryki romantycznej. Najbardziej ciekawe pod względem odniesień intertekstualnych mogą okazać się w takim zestawieniu XVIII sonet z cyklu odeskiego Mickiewicza - Do D. D. Wizyta i Norwidowski liryk Czemu.

Oba cykle sonetowe, opublikowane przez Mickiewicza w 1826 roku charakteryzuje znaczny stopień formalnej, „zewnętrznej” dialogowości. Przy ich okazji często wspomina się o nowatorstwie gatunkowym, przejawiającym się we wprowadzeniu w obręb klasycznej formy sonetowej licznych kwestii dialogowych ${ }^{12}$ (rozmów Pielgrzyma z Mirzą czy też dialogów prowadzonych przez bohatera odeskiego cyklu sonetowego z kolejnymi adresatkami kobiecymi). Czesław Zgorzelski określa nawet część tych sonetów mianem „miniaturowej trylogii spotkań"13. Bez wielkiej przesady można by powiedzieć, że oba cykle sonetów Mickiewiczowskich (odeski i krymski) cieszyły się wielką popularnością przez cały wiek XIX. Dlatego nie dziwi wcale, że Norwid postanowił nawiązać dialog poetycki właśnie z jednym z tych so-

12 Na marginesie warto zasygnalizować, że zewnętrzne udramatyzowanie scenerii lirycznej pojawiło się w literaturze polskiej już wcześniej, u Karpińskiego, którego tradycja poetycka była - jak wiadomo - bardzo dla Mickiewicza ważna. Widać je wyraźnie chociażby w sielance Laura $i$ Filon, choć trzeba zwrócić uwagę także na specyficzne, otwarte na dialog ukształtowanie wypowiedzi podmiotu lirycznego w sielance $O$ Justynie. Rzecz jasna, trudno byłoby dopatrywać się w wymienionych tu tekstach znamion polifonii pokroju Norwida czy Dostojewskiego, ale warto mieć je w pamięci w celu uświadomienia sobie ciąłości tradycji poetyckiej.

13 Czesław Zgorzelski, O sonetach odeskich, w: tenże, O sztuce poetyckiej Mickiewicza. Próby zbliżeń i uogólnień, Warszawa 1976, s. 243. 
netów, poruszającym tak ważną dla młodszego twórcy problematykę konwersacji salonowej i kobiety.

Wysuniętą na plan pierwszy cechą Mickiewiczowskiej Wizyty, jest jej żartobliwy charakter. Opis niekończącego się korowodu odwiedzin salonowych, uniemożliwiającego pozostanie zakochanym sam na sam, jest modelowany w znacznym stopniu z pozycji humorystycznej. Punkt ciężkości spoczywa tu na hiperbolizującym przedstawieniu pełnego napięcia wewnętrznego oczekiwania podmiotu lirycznego na to, żeby „słów kilka pomówić z nią samą”. Z tego też zapewne wynika nieco groteskowe przedstawienie wyimaginowanych sposobów, które miałyby przyczynić się do położenia kresu kolejnym wizytom:

Gdym mógł, progi wilczą otoczyłbym jamą,

Stawiłbym lisie pastki, kolczate okowy,

A jeśli nie dość bronią, uciec bym gotowy

$\mathrm{Na}$ tamten świat stygową zasłonić się tamą ${ }^{14}$.

Zawarta w dwóch pierwszych wersach terminologia myśliwska (na marginesie warto zauważyć, że stanowi ona rodzaj nawiązania do wcześniejszych ,petrarkowskich”- w terminologii Zgorzelskiego - ogniw cyklu, szczególnie do sonetu Strzelec) przeradza się ostatecznie w pragnienie ucieczki „na tamten świat”, na drugą stronę mitycznego Styksu. Nie bez znaczenia pozostaje też to, że bohater wiersza pragnie uciec tam... samotnie, bez ukochanej. Zresztą w ogóle wspomnienie o bohaterce $\mathrm{i}$ adresatce sonetu pojawia się w całym wierszu jedynie raz, w pierwszym wersie, co jest skądinąd w pełni zgodne z opisaną przez Zgorzelskiego logiką rozwoju cyklu odeskiego ${ }^{15}$. Ale i ta wzmianka ma charakter pośredni. Całość wiersza skupia się głównie na odczuciach podmiotu lirycznego, stanowi przede wszystkim opis jego zniecierpliwienia, na które - w obliczu obowiązujących konwencji towarzyskich - nie ma żadnej rady.

14 Adam Mickiewicz, Do D. D. Wizyta, w: tenże, Dzieła, t. 1, Wiersze, oprac. W. Borowy, E. Sawrymowicz, Warszawa 1955, s. 252.

15 Czesław Zgorzelski, O sonetach..., dz. cyt.. 
Zupełnie inaczej pod tym względem prezentuje się Norwidowy liryk Czemu, choć również i on został ujęty w formę monologową, skupiającą się na opisie stanu psychicznego bohatera wiersza, uwięzionego w salonie i pozbawionego możliwości, żeby choć przez chwilę porozmawiać z ukochaną bez świadków ${ }^{16}$. Jest to jednak monolog (w pewien sposób) pozorny ${ }^{17}$. Bohater liryczny opisuje w nim ,siebie jako Innego", zwraca się sam do siebie jako do Innego:

Próżno się będziesz przeklinał i zwodził,

I wiarołomił zawzięciu własnemu -

Powrócisz do niej - będziesz w progi wchodził

I drżał, że - może nie zastaniesz?... c z e $\mathrm{m} u$ u ...

(II, 118) $)^{18}$

Tego rodzaju „rozwarstwienie” samoświadomości autora jest zdaniem Bachtina - elementem niezbędnym do estetycznej konkretyzacji bohatera jako „sensownej całości”:

Patrząc na siebie oczyma drugiego człowieka, zawsze w życiu zwracamy się ponownie ku sobie. Ostatnie, jak gdyby podsumowujące zdarzenie rozgrywa się wtedy w nas samych, w kategoriach naszego własnego życia. Do tego ponownego wejścia w siebie nie powinno jednak dochodzić przy estetycznej samoobiektywizacji autora-człowieka w bohatera. Dla autora jako innego postać bohatera ma stanowić całość ostateczna, która oddzieli go od bohatera. Autor musi tu przeprowadzić zdecydowaną granicę między sobą a bohaterem, skonkretyzować się w wartoś-

16 Zob. najlepszą interpretację tego liryku, autorstwa Ireneusza Opackiego, Poezja romantycznych przełomów, Wrocław 1972.

17 Kwestią domagającą się osobnego rozważenia jest status gramatyczno-stylistyczny tytułowego pytania. Z jednej strony samoczynnie narzuca się refleksja o tym, że jest to jedynie pytanie retoryczne, z drugiej zaś - należy wziąć pod uwagę również możliwość tego, że jest to pytanie rzeczywiste, skierowane do Najwyższego Adresata i uporczywie (na sposób nieco dziecięcy) domagające się odpowiedzi.

18 Wszystkie cytaty z utworów Norwida podaję za wydaniem: Cyprian Norwid, Pisma wszystkie, zebrał, tekst ustalił i uwagami krytycznymi opatrzył J. W. Gomulicki, t. I-XI, Warszawa 1971-1976. Lokalizacja cytatów podawana będzie w nawiasie w tekście głównym. Liczba rzymska oznacza numer tomu, arabska - strony. 
ciach czystych dla innego człowieka, a ściślej - w pełni rozpoznać go W sobie ${ }^{19}$.

Można sądzić, że zgodnie z tokiem rozumowania Bachtina, w czytanym obecnie wierszu dochodzi właśnie do takiego ,rozpoznania w sobie" bohatera przez autora. Jak możemy się domyślać na podstawie licznej zachowanej korespondencji Norwida, sytuacja duchowo-salonowa zobrazowana w wierszu nie była poecie obca. Wart uwagi jest fakt, że Norwid nie przemawia w tym liryku w pierwszej osobie, opowiadając o swoich doznaniach, ale właśnie zw rac a s i ę do swojego bohatera, przemawia doń z pewnego dystansu, w którym mieszają się dwa porządki: humorystyczny i empatyczny ${ }^{20}$. Wskazany jako pierwszy, porządek humorystyczny, zdaje się mieścić w relacji intertekstualnej wobec przywoływanego wcześniej Mickiewiczowskiego sonetu. Od strony ,zewnętrznej” sytuacja obu bohaterów jest bardzo podobna: obaj są zmuszeni do przestrzegania etykiety salonowej, niepozwalającej na bezpośredni kontakt z ukochaną. Obaj też są skłonni do przedstawiania swoich doznań w sposób nieco egzaltowany, przesadny. Na tym jednak podobieństwa się kończą. Wiersz Mickiewicza w tym konkretnym kontekście (abstrahującym od wymowy całego cyklu) jest jedynie rodzajem komplementu salonowego, elementem rozgrywki miłosnej. Z kolei liryk Norwida aspiruje do przedstawienia znacznie głębszych stanów duchowych, o czym za chwilę. Na płaszczyźnie humorystycznej podmiot liryczny przygląda się swojemu bo-

19 Michał Bachtin, Autor i bohater w działalności estetycznej, w: tenże, Estetyka twórczości słownej, tłum. D. Ulicka, opracowanie przekładu i wstęp E. Czaplejewicz, Warszawa 1986, s. 49. Choć później w tym samym artykule Bachtin odsądza od czci i wiary cały rodzaj liryczny jako poniekąd ,etycznie podejrzany”, będący egzemplifikacją czystego zniewolenia bohatera przez autora, to jednak wydaje się, że jego uwagi dotyczące problematyki autor - bohater w ogóle mogą być bardzo przydatne przy analizie wielogłosowej liryki Norwida. Na temat stosunku Bachtina do liryki: „Pozycja autora jest tu [w liryce] silna i autorytatywna, zaś samodzielność bohatera i jego życiowych intencji - minimalna. Bohater nieomal nie ż y j e, lecz tylko o d z w i e r c i e d la s i ę w duszy aktywnego twórcy - panującego nad nim innego człowieka" (tamże, s. 234).

20 Naturalnie, teza o humorystyczności Czemu jest niezgodna z tokiem interpretacji tego wiersza, dokonanej przez Opackiego. Zob. Ireneusz Opacki, Słowackiego równanie z jednq niewiadoma, w: tenże, Poezja romantycznych przełomów. Szkice, Wrocław-Gdańsk 1972, s. 53-56. 
haterowi z trudnym do precyzyjnej eksplikacji łagodnym humorem. Przejawia się on głównie w licznych w tym wierszu antytezach: nie będziesz chciał wrócić, ale powrócisz; „Będziesz się be z niej z nią kłócił - i godził”, czujesz się nieszczęśliwy, ale „szczęśliwi przyjdą”, etc., etc. ${ }^{21}$

Ta ciagła „,szarpanina” wewnętrzna uaktywnia w wierszu drugi plan mówienia - plan empatii podmiotu lirycznego (autora) wobec bohatera. Obrazy duchowej rozterki, niepewności, poczucia niespełnienia i może poniekąd też lekceważenia przedstawione w czterech pierwszych strofach, sięga apogeum w decyzji o opuszczeniu salonu przez bohatera:

Aż chwila przyjdzie, gdy w y j ść ? - lepiej znaczy,

Niżeli zostać po obojętnemu;

Wstaniesz - i pójdziesz, kamienny z rozpaczy,

I nie zatrzymasz się, precz idąc -- c z e $\mathrm{m} u$ ?

(II, 119)

Gest opuszczenia salonu, jedyny znaczący, „nośny” gest dostępny $\mathrm{w}$ tej chwili bohaterowi wiersza, $\mathrm{z}$ jednej strony mocno kojarzy się z ,zużytym” już w czasach Norwida romantycznym rozwiązaniem fabularnym (skarykaturyzowanym już nawet przez samego Mickiewicza w scenie ostatecznej kłótni Tadeusza i Telimeny). Z drugiej strony zmiana przestrzeni „dusznego”, wypełnionego przerażającym „Legionem" gości salonu, na przestrzeń otwartą i naturalną, umożliwia wprowadzenie do wiersza dodatkowych konotacji, związanych z relacją natura - Bóg - człowiek:

A księżyc będzie, jak od wieków, niemy,

Gwiazda się żadna z nieba nie poruszy -

Patrząc na ciebie oczyma szklistemi,

Jakby nie było w Niebie żywej duszy:

21 Na temat możliwości odczytania fragmentów Czemu jako nacechowanych ironicznie por. Stanisław Falkowski, Między wyznaniem, drwinq i pouczeniem (Cypriana Norwida „Czemu”), w: , Czemu” $i$,,Jak” czytamy Norwida, red. J. Chojak, E. Teleżyńska, Warszawa 1991, s. 24-25. 
Jakby nie mówił nikt $\mathrm{N}$ i e w i d z i a l n e mu,

Że trochę niżej - tak wiele katuszy!

I nikt, przed Bogiem, nie pomyślił: c z e m u ?

(tamże)

Przywołana wyżej zamykająca strofa wiersza może być traktowana jako klucz do odczytania jego całościowego przesłania. Właśnie tu zbiegają się rozmaite porządki (etyczny, żartobliwy, kulturowy i semiotyczny), sygnalizowane we wcześniejszych fragmentach liryku. Zaznaczona poprzednio opozycja przestrzenna wnętrze-zewnętrze, salon-otwarta przestrzeń, kultura-natura zyskuje tu mocne rozwinięcie. Wprowadzony na początku strofy przeciwstawny spójnik ,„a”, nieumotywowany ani pod względem składniowym, ani myślowym, zdaje się odwoływać bezpośrednio do nieujawnionych wprost ,kulturowych” i ,literackich” oczekiwań bohatera. Przecież „od wieków” w większości liryków miłosnych księżyc był atrybutem zakochanych, to właśnie jego „srebrna poświata” była podstawowym składnikiem ich (koniecznie potajemnych) schadzek. Więc w tym sensie księżyc zdecydowanie „niemy” nie był.

Kolejny wers wprowadza motyw gwiazd. Jest on także, poczynając od czasów nowożytnych, kolejnym stałym składnikiem liryki miłosnej. Tutaj, w wierszu Norwida, gwiazdy pozostają nieruchome, czyli w kontekście podstawowej europejskiej symboliki kulturowej: po prostu nie zdradzają najmniejszej ochoty, żeby spaść i tym samym przyczynić się do spełnienia życzenia nieszczęśliwego kochanka.

Zarówno nieprzychylność przestrzeni salonowej, jak i milczenie, nieruchomość natury (natury przypominającej tu raczej dekoracje teatralne niż przestrzeń prawdziwa) sprawiaja, że bohater zostaje odsunięty od podstawowych, utartych w kulturze XIX wieku źródeł poszukiwania spełnienia lub przynajmniej pocieszenia. Podmiot liryczny wiersza w ten sposób dialoguje nie tylko z samym bohaterem, mó wiąc do niego o n i m, ale też z zastaną tradycją liryki miłosnej. Stopniowe, nieco humorystyczne ogołacanie bohatera $\mathrm{z}$ rozmaitych iluzji na temat tego, jak zwykle ,powinni” zachowywać się zakochani młodzieńcy, ostatecznie zmusza bohatera do „spojrzenia w górę”. 
Bardzo ciekawe pod tym względem jest niejednoznaczne, ,ciemne” zakończenie wiersza. Trzeba tu - chyba - przyznać rację Stanisławowi Falkowskiemu, interpretującemu końcowe wersy Czemu jako uznanie boskiej opieki nad światem:

Dodatkowym kluczem do ustalenia sensu ostatniego wersu powinna być odpowiedź na pytanie, w jakim znaczeniu Norwid użył w nim wyrażenia przed Bogiem. [...] Jeżeli [...] uznać, że przed Bogiem znaczy 'wcześniej niż Bóg' lub: 'oprócz Boga, poza Bogiem', wówczas ostatnie zdanie stanowi raczej samodzielną całość składniową i zawiera stwierdzenie, że nikt prócz Boga nie pomyślał, jakie są przyczyny (lub: jaki jest sens) ziemskich cierpień ludzi, ale właśnie Bóg pomyślał!22

Powtarzające się w tej ostatniej strofie dwukrotnie określenie ,jakby", stawiające pod znakiem zapytania obecność Boga w niebie i Jego czuwanie nad ludźmi, pełni w planie gramatyczno-dialogowym wiersza funkcję wyjątkowo skomplikowaną. Przede wszystkim nie wiadomo dokładnie do kogo owo ,jakby” należy: czy zostało ono ,wyjęte” z mowy wewnętrznej bohatera wiersza i stanowi autoegzemplifikację jego stanu duchowego (odczucia pustki i osamotnienia)? Czy też jest to rodzaj chwytu anakrytycznego, wykorzystany przez podmiot liryczny wiersza do sprowokowania wewnętrznego ruchu bohatera? Do wywołania gwałtownego otrząśnięcia się z nieznośnego uczucia pustki i odrzucenia, do zmiany kontekstu, w którym natarczywie pojawia się tytułowe pytanie? Do spojrzenia na siebie nie „w świetle niemego księżyca", ale - Boskiej Opatrzności? Jeśli Norwid w tych finalnych wersach rzeczywiście wprowadza anakryzę, głębszego sensu nabiera całość dialogowego ukształtowania wiersza. W tym ujęciu dialogowe (w sensie Bachtinowskim) zwracanie się podmiotu lirycznego do bohatera zdecydowanie zyskałoby na celowości i określoności. Opis negatywnego stanu duchowego Innego, na dodatek skierowany właśnie do tego Innego, ujawnia w tym świetle cel nie tylko empatyczny (,wiem, co czujesz; współodczuwam razem z tobą”), ale też może

22 Stanisław Falkowski, Między wyznaniem, drwinq i pouczeniem..., dz. cyt., s. 19-20. 
mieć działanie terapeutyczne (,wiem, co czujesz; współodczuwam z tobą; wiem, jak ci pomóc zacząć czuć się inaczej”). Józef Fert zastanawiał się w początkowym rozdziale swojej rozprawy o dialogowości Norwida nad tym, „co może być między Ja i Ty”23. Norwid wyraźnie odpowiada na to pytanie: między Ja i Ty powinien zawierać się dialog, dialog w rozumieniu etycznym, zakładającym nie tylko współistnienie rozmówców i posługiwanie się przez nich tym samym kodem językowym, ale też ich dogłębne porozumienie, do którego czasem (jak to stało się w wierszu Czemu) niezbędna może się okazać mała prowokacja myślowa ${ }^{24}$.

\section{Rozmowa z sobą jako Innym u Dostojewskiego}

Również i w twórczości Dostojewskiego chwyt konstrukcyjny prowadzenia rozmowy ze sobąjako Innym pojawia się wyjątkowo często, częściej nawet niż to się dzieje u Norwida. Tyle że pisarz rosyjski raczej nie każe swoim bohaterom prowadzić soliloquiów (choć pewnym wyjątkiem mogą tu być np. rozważania Człowieka z Podziemia czy narratora Łagodnej), ale z reguły tworzy dla nich konkretnych rozmówców o nie zawsze pewnym statusie ontologicznym. Zwykle Dostojewski wykorzystuje do tego celu wielokrotnie odnotowywany przez badaczy schemat „sobowtórowy”: poczynając od panów Goladkina Starszego i Młodszego, przez Raskolnikowa i Swidrygajłowa, na Iwanie i Diable kończąc. Szczególnie ciekawy wydaje się ten ostatni przykład. Tym bardziej, że w Braciach Karamazow relacja „,sobowtórowa" jest szczególnie skomplikowana. Iwan został przecież w powieści obdarzony dwoma „sobowtórami mentalnymi”: Smierdiakowem i Diabłem. Dialog Iwana z każdą z tych postaci jest innym rodzajem rozmowy z sobą samym, bezpośrednim w przypadku wykreowanej

23 Józef F. Fert, Norwid poeta dialogu, Wrocław-Łódź 1982, s. 9.

24 Naturalnie liryk Czemu może być traktowany również jako rodzaj soliloquium, zwrotu do samego siebie. Jednak wydaje się, że przedstawiona wyżej interpretacja nie musi pozostawać w sprzeczności z możliwością odczytania wiersza jako rozmowy ze sobą jako Innym. 
przez jego wyobraźnię postaci Diabła i nieco bardziej zakamuflowanym w przypadku Smierdiakowa.

Bachtin w monografii poświęconej Dostojewskiemu parokrotnie zwraca uwagę na szczególny sposób komunikacji Iwana i Smierdiakowa. Wyjątkowość ich dialogów polega - zdaniem badacza - na tym, że lokaj zdaje się odpowiadać na niewypowiedziane wprost sugestie młodego Karamazowa ${ }^{25}$. Jednak specyfika tych rozmów polega może nie tyle na niedopowiedzeniach i przemilczeniach jednego z tytułowych braci, co raczej na wyjątkowo głębokim porozumieniu wewnętrznym postaci, którego natury Iwan Karamazow nie jest chyba do końca świadomy. Szczególnie interesujący pod względem tej podwójnej komunikacji okazuje się rozdział Braci Karamazow pt. Tymczasem jeszcze bardzo niejasny. W jego początkowym fragmencie narrator wyraźnie opisuje stosunek, jakim Iwan darzy Smierdiakowa:

Chodzi o to, że Iwan Fiodorowicz ostatnimi czasy, a zwłaszcza w ostatnich dniach nie cierpiał tego człowieka [Smierdiakowa]. Co więcej, zdawał sobie sprawę z rosnącej prawie nienawiści do tej kreatury. Może ów proces nienawiści tak się zaostrzył dlatego właśnie, że na początku, zaraz po przyjeździe Iwana Fiodorowicza, rzecz miała się zgoła inaczej. Wówczas bowiem Iwan Fiodorowicz zainteresował się jakoś szczególnie Smierdiakowem, miał go nawet za bardzo oryginalnego człowieka. Ośmielił go do pogawędek [...]. Tak czy owak prędko ukazała się bezgraniczna ambicja Smierdiakowa, a w dodatku ambicja urażona. Nie spodobało się to bardzo Iwanowi Fiodorowiczowi. Stąd właśnie powstała jego odraza ${ }^{26}$.

25 Por.: „W zamyśle Dostojewskiego Iwan chce zabić ojca, ale chce pod warunkiem, że sam nie tylko zewnętrznie, ale i w e w nę tr z n i e nie będzie miał z tym nic wspólnego. Chce, aby zabójstwo się wydarzyło jako nieubłagalny wyrok losu nie tylko p o m i m o jego woli, ale i w b r e w niej. Mówi Aloszy: «Pamiętaj, że ja zawsze stanę w jego obronie. A co do moich pragnień, zastrzegam sobie w danym wypadku zupełną swobodę». [...] W ten sposób budowany jest dialog wewnętrzny Iwana z sobą samym. Smierdiakow odgaduje, a właściwie wyraźnie słyszy drugą replikę tego dialogu, ale ukryty w niej wybieg rozumie po swojemu: jako dążenie Iwana, by nie dać najmniejszego dowodu swego współudziału w zbrodni, jako najdalej posuniętą wewnętrzną i zewnętrzną ostrożność «mądrego człowieka», który unika jakichkolwiek bezpośrednich sformułowań mogących go obciążyć, z którym zatem «i porozmawiać ciekawie», bo można używać wyłącznie aluzji”. (Michał Bachtin, Problemy..., dz. cyt., s. 289).

26 Fiodor Dostojewski, Bracia Karamazow. Powieść w czterech częściach z epilogiem, thum. A. Wat, t. 1, Warszawa 1959, s. 324. 
Iwan Karamazow bezbłędnie zauważa łączące go z lokajem podobieństwo ukształtowania mentalnego. Jednocześnie Smierdiakow jawi mu się jako karykaturalna wersja jego samego. Ten rodzaj „karnawałowego" podobieństwa między domniemanymi braćmi wywołuje u Iwana odrazę wobec Smierdiakowa i głęboki podziw lokaja wobec Iwana.

Charakterystyczny pod względem opisu zachowania Iwana wobec Smierdiakowa może się okazać następujący fragment powieści:

Pełen wstrętu i irytacji chciał teraz przejść, milcząc i nie patrząc na Smierdiakowa. Lecz ów wstał z ławki. Iwan Fiodorowicz w jednej chwili zrozumiał z tego ruchu, że przebrzydły fagas umyślnie na niego czekał i chce mu coś szczególnego powiedzieć. Spojrzał więc nań i zatrzymał się. I to, że zatrzymał się tak nagle i nie poszedł dalej, jak zamierzał był przed chwilą, rozzłościło go do żywego ${ }^{27}$.

Smierdiakow został obdarzony przez autora powieści jakimś szczególnym rodzajem władzy nad Iwanem Karamazowym, wynikającym chyba z subtelnego wewnętrznego podobieństwa obu postaci. Smierdiakow jest jakby fizycznym ucieleśnieniem najbardziej gnuśnych idei i pragnień Iwana. Stąd też biorą się ta szczególna władza nad nim, którą dyskretnie manifestuje lokaj, i to wyjątkowe obrzydzenie, odczuwane przez Karamazowa względem służącego i też siebie samego w relacji ze Smierdiakowem.

Jednym z najbardziej gorących pragnień służącego jest wysłanie Iwana do Czermaszni. Dopiero po jego wyjeździe, bez żadnych zakłóceń, będzie mogła rozegrać się scena morderstwa Fiodora Karamazowa. Smierdiakow, czując mentalne przyzwolenie Iwana na ojcobójstwo, streszcza mu swój plan działania. Jednocześnie nic w tej szczególnej, podwójnej rozmowie nie zostaje powiedziane wprost. Pozwala to Iwanowi na spokojny wyjazd i próbę oszukania samego siebie, że w trakcie jego nieobecności w domu ojca nie stanie się nic złego. Warto przyjrzeć się dokładniej konstrukcji tej ,niejasnej” rozmowy.

\footnotetext{
27 Tamże, s. 317.
} 
Początkowo Smierdiakow przypomina Iwanowi o prośbie ojca. „Czemuż to pan do Czermaszni nie jedzie?” Pytanie to - choć na pozór zupełnie niewinne - wywołuje gwałtowne oburzenie Iwana: „E, do licha, gadaj wyraźniej, o co ci chodzi - zawołała wreszcie z gniewem Iwan, wpadając nagle z uprzejmości w grubiaństwo". W dalszej kolejności Smierdiakow zaczyna użalać się na swoje trudne położenie, wynikające z rywalizacji starego Karamazowa i Dymitra o względy Gruszeńki. Ojciec i syn obrali Smierdiakowa na swojego powiernika i jednocześnie obaj grożą mu śmiercią, jeśli okaże brak lojalności względem nich.

Następnie okazuje się, że po wyjeździe Iwana, Smierdiakow może dostać wyjątkowo ostrego ataku padaczki:

- Jaka to znowu padaczka?

- Długi atak taki, bardzo długi. Kilka godzin, a nieraz to i dzień cały, i dwa dni trwa. Raz to nawet trzy dni trwało, ze strychu wtedy spadłem. Przestanie mnie trząść i znowu zacznie; a ja przez te trzy dni nie mogłem przyjść do rozumu. [...]

- A przecież mówią, że nie można z góry przewidzieć, o której godzinie nastąpi atak. Jakże możesz twierdzić, że jutro dostaniesz? - zapytał Iwan Fiodorowicz z jaką́s nerwową ciekawością.

- Tak jest, nie można przewidzieće ${ }^{2}$.

Smierdiakow stopniowo, krok po kroku thumaczy Iwanowi, w jaki sposób dojdzie do morderstwa ich ojca. Jednocześnie nic nie zostaje powiedziane wprost. Ten sposób mówienia, będący zarazem - jak się można domyślać - rodzajem eksplikacji wewnętrznych rozważań Iwana, pozwala mu na zachowanie zewnętrznego pozoru niewiedzy, na niedopuszczenie do siebie jasnej świadomości tego, że rozważania o mentalnym ojcobójstwie opuściły przestrzeń dywagacji teoretycznych i przekształciły się w rzeczywiste planowanie zbrodni. Smierdiakow, wchodząc w świat filozoficzno-etycznych rozważań Iwana, po-

28 Tamże, s. 319. 
pełnia rzeczywiste morderstwo, do którego sam Karamazow nie byłby raczej zdolny ${ }^{29}$.

Jednak służący pozostaje - mimo wszystko - jedynie nieudolnym sobowtórem Iwana. Jego pragnienie całkowitego związania się z nim przez gest morderstwa Karamazowa-ojca, przeistoczenie się w żywą manifestację wszystkich, nawet najbardziej obrazoburczych idei Iwana Fiodorowicza kończy się klęską. Smierdiakow, zdając sobie sprawę z głębokiej odrazy, jaką czuje doń Iwan, będący poniekąd jego mentalnym „Stwórcą”, popełnia samobójstwo.

Znacznie bardziej ,wprost” został przez Dostojewskiego ukształtowany szereg rozmów Iwana z jego drugim sobowtórem - Diabłem.

Iwan, cierpiący na ,rozstrój nerwowy”, został nawiedzony przez „Diabła”, który

Miał na sobie jakiś brązowy tużurek, widocznie od lepszego krawca, ale już zniszczony, uszyty zapewne trzy lata temu i całkiem już niemodny żaden zamożny światowiec od dwóch lat nie nosił takiego fasonu. [...] Gość czekał i siedział właśnie niby rezydent, który dopiero co zszedł z wyznaczonego mu pokoju na dól, na herbatkę, aby dotrzymać gospodarzowi towarzystwa - lecz milczy posłusznie, bo gospodarz, zajęty i zasępiony, o czymś myśli ${ }^{30}$.

Iwan, przez cały czas rozmowy ze swoim gościem-rezydentem usiłuje przekonać sam siebie, że Diabeł jest jedynie wytworem jego imaginacji, fantastycznym ucieleśnieniem gorszej wersji jego samego:

- Ani przez chwilę nie uważam cię za realną prawdę - zawołał Iwan z jakąś wściekłością. - Jesteś kłamstwem, moją chorobą, jesteś marą. Tylko nie wiem, jak cię zniszczyć, i widzę, że przez pewien czas trzeba będzie pocierpieć. Jesteś moją halucynacją. Jesteś usposobieniem mojego własnego ja, zresztą tylko jednostronnym... jesteś wcieleniem moich myśli

${ }^{29}$ W tym rozszczepieniu postaci (panicz-intelektualista i lokaj-wykonawca) widać coś bardzo wyraźnie przypominającego innego bohatera Dostojewskiego - Raskolnikowa. Tyle, że Rodion Romanowicz wciela się w obie role: mordercy i intelektualnego, i rzeczywistego.

30 Fiodor Dostojewski, dz. cyt., t. 2, s. 350-351. 
i uczuć, ale najbardziej obmierzłych i głupich. Pod tym względem mógłbyś mnie nawet zainteresować, gdybym tylko miał więcej czasu, żeby się tobą zajmować... ${ }^{31}$

Nawiedzająca Iwana chorobliwa projekcja mentalna Diabła została do szczętu pozbawiona przez autora „dreszczyku metafizycznego”, od początku bowiem wiadomo, że gość Iwana jest jedynie halucynacją. Natomiast bardzo ciekawe wydają się tematy ich rozmów, zwłaszcza drugiej z nich.

Podstawowym problemem etyczno-filozoficznym, dręczącym Iwana jest kwestia istnienia Boga oraz możliwość pojawienia się na świecie człowieka-boga, ustanawiającego nową moralność, według której „wszystko będzie dozwolone”. Ten problem filozoficzny jest już oczywiście - dobrze znany z poprzednich powieści Dostojewskiego: ze Zbrodni i kary czy też Biesów. Jednak Bracia Karamazow, na płaszczyźnie światopoglądowej mieli pełnić funkcję znacznie donioślejszą niż utwory wcześniejsze. Dlatego do znanego już z innych jego powieści typu rosyjskiego inteligenta-ateisty wprowadził autor pewne zmiany. Popełniona przezeń na płaszczyźnie moralnej zbrodnia, nie ma już tak dosadnego charakteru, jak opisane ze wszystkimi szczegółami zabójstwo starej lichwiarki i jej siostry, w Zbrodni i karze czy też szereg morderstw, popełnionych przez bohaterów Biesów. Gest zabójstwa Fiodora Karamazowa zyskuje tu o wiele więcej wymiarów niż „tylko” mord dokonany przez jednego człowieka na drugim. Podstawowym zagadnieniem, mogącym pozwolić na tego rodzaju sprzeniewierzenie się prawom boskim i ludzkim, jest problem istnienia Boga. Jeśli Boga nie ma, to wszystko jest dozwolone - mówi Iwan, a za nim powtarza to Smierdiakow, popełniając morderstwo. Jednak Iwan staje się wyłącznie zabójcą intelektualnym. Świadomość tego, że stał się ,,autorem” popełnionej przez Smierdiakowa zbrodni i pośrednio przyczynił się też do oskarżenia Dymitra, staje się dlań niemalże nie do zniesienia. I właśnie w tej chwili jego umysł tworzy projekcję rozmówcy-Diabła.

\footnotetext{
31 Tamże, s. 353.
} 
Choć Iwan usiłuje cały czas pamiętać o tym, że natarczywy gość jest jedynie wytworem jego rozgorączkowanego umysłu i że rozmawiając z nim prowadzi w istocie dialog z samym sobą, postanawia zadać mu jedno z kluczowych dla powieści pytań:

- To i ty w Boga już nie wierzysz? - uśmiechnął się z nienawiścią Iwan.

- To znaczy, jak by ci tu powiedzieć, jeśli ty rzeczywiście na serio...

- Jest Bóg czy nie ma? - zawołał Iwan z gniewną natarczywościąa

Diabeł, zgodnie z logiką kreacji tej postaci (a Iwan przecież jest w pewnym stopniu ,poetą”, rzecz jasna, nie pali się do bezpośredniej odpowiedzi. Zamiast tego przywołuje kilka opowieści, wymyślonych przez samego Iwana: przede wszystkim ,poemat o Wielkim inkwizytorze". Zwłaszcza przywołanie tego ostatniego utworu, który poprzednio zaistniał na stronach powieści w zupełnie innym kontekście myślowym (przecież to Iwan - poniekąd - odgrywał rolę diabła-kusiciela, opowiadając tę historię Aloszy), sprawia, że w sumieniu bohatera następuje pewna zmiana:

- Zabraniam ci mówić o Wielkim inkwizytorze! - zawołał Iwan rumieniąc się ze wstydu.

- No, a Przewrót geologiczny? Pamiętasz? To ci dopiero poemacik!

- Milcz, bo cię zabije!

- Mnie zabijesz? Nie, wybacz, ale co mam do powiedzenia, powiem. Przyszedłem właśnie po to, aby się uraczyć tą przyjemnością. O, lubię marzenia moich przyjaciół, zapalczywych, młodych, rwących się do życia! ${ }^{33}$

Iwan w żaden sposób nie był w stanie uzyskać od „diabła swojej podświadomości" jednoznacznej odpowiedzi na pytanie o istnienie Boga. Natomiast udało mu się uzyskać coś chyba znacznie cenniejszego: poczucie wstydu, wywołane wcześniejszą przeintelektualizowaną niewiarą. Diabeł skutecznie wydrwił wcześniejsze koncepcje etyczno-filozoficzne swojego „młodego przyjaciela”. Podświadomość Iwana (moż-

\footnotetext{
32 Tamże, s. 359.

33 Tamże, s. 366-367.
} 
na by powiedzieć) spisała się na medal. Wydaje się, że dla tego rodzaju osobowości, jaką prezentuje ,autor poemacików” nie ma nic gorszego niż trafna drwina, otwierająca mu oczy na wcześniejsze błędy.

Prowadzony w powieściach Dostojewskiego dialog z sobą jako Innym w pierwszej chwili może sprawiać wrażenie znacznie bardziej kunsztownego niż taki ,autodialog” u Norwida. Jednak odrzucając na bok odmienności konstrukcyjne, łączące się z różnicami gatunkowymi, można stwierdzić, że zarówno sposób budowania takiego dialogu, jak i jego cel strukturalny są we wskazanych wyżej przykładach podobne. Zarówno bohater wiersza Czemu, jak i Iwan Karamazow znajdują się w chwilach na swój sposób krytycznych. Rozmowa ze sobą jako Innym pozwala im przyjrzeć się sobie z odpowiedniego dystansu: bohater Norwidowego wiersza ma okazję zauważyć humorystyczny aspekt swojego położenia, a Iwan - pod wpływem rozmów ze Smierdiakowem i Diabłem - zauważa własną brzydotę moralną zaczyna czuć do niej głęboką odrazę i jednocześnie wstydzi się jej pseudofilozoficznych źródeł. Naturalnie, sytuacja liryczna wykreowana przez Norwida jest pod względem moralnym znacznie „lżejsza”. W tym momencie chodzi jednak nie o prezentację estetyki literackiej obu twórców, ale raczej o wskazanie na podobną funkcję strukturalną wielogłosowych fragmentów ich dzieł, nieuchronnie prowadzącą do relacji Bóg - człowiek. Zresztą, jak zauważa Bachtin, nikt z nas nie jest Adamem, wypowiadającym słowa po raz pierwszy i każda z naszych wypowiedzi, skierowanych do jakiegokolwiek drugiego człowieka, ma również najważniejszego Adresata $^{34}$.

\section{„Artystyczna wola polifonii" a problem tradycji}

Norwid został określony przez Józefa Ferta mianem ,poety dialogu"35. Rzeczywiście, wystarczy nawet pobieżnie przejrzeć wier-

34 Por. Michał Bachtin, Problem gatunków mowy, w: tenże, Estetyka twórczości słownej, tłum. D. Ulicka, oprac. i wstęp E. Czaplejewicz, Warszawa 1986, s. 394-402.

35 Józef F. Fert, dz. cyt. 
sze poety, żeby przekonać się (nawet na zasadzie graficznej) o niezwykle częstym wprowadzaniu kwestii dialogowych do jego tekstów poetyckich. Przykładem takiego utworu, składającego się w znacznym stopniu z przenikających się i przeciwstawnych wobec siebie zdań jest drugie ogniwo Vade-mecum - wiersz Przeszłość $c^{36}$ :

\section{1}

Nie Bóg stworzył p r z e s zł o ś ć, i śmierć, i cierpienia,

Lecz ów, co prawa rwie;

Więc - nieznośne mu dnie;

Więc, czując złe, chciał odepchnąć s p o m n i e n i a!

2

Acz nie byłże jak dziecko, co wozem leci,

Powiadając: „O! dąb

Ucieka!... w lasu głąb..."

- Gdy dąb stoi, wóz z sobą unosi dzieci.

3

Pr ze s zło ść - jest to d z i ś, tylko cokolwiek daléj:

Za kołami to wieś,

Nie jakieś tam c o ś, g d zi eś,

Gdzie nigdy ludzie nie bywali!...

(II, 18)

Wiersz rozpoczyna się od dialogowej riposty, zdecydowanie przeciwstawiającej się twierdzeniu Innego o tym, że to „Bóg stworzył przeszłość". To ujęcie problemu w pierwszej chwili może wydać się zaskakujące. Dziwić może przede wszystkim to, że przeszłość została tu wymieniona przez podmiot liryczny w jednym szeregu ze śmiercią i cierpieniem. Tego rodzaju ujęcie tradycji (nieuchronnie łączącej się

36 Na temat interpretacji tego wiersza zob. np. Jacej Trznadel, Czytanie Norwida. Próby, Warszawa 1978. Antoni Dunajski, Chrześcijańska interpretacja dziejów w pismach Cypriana Norwida, Lublin 1985. Sławomir Rzepczyński, Nad „Przeszłościa” Norwida, w: Czytajac Norwida. Materiały z konferencji poświęconej interpretacji utworów Cypriana Norwida zorganizowanej przez Katedrę Filologii Polskiej Wyższej Szkoły Pedagogicznej w Stupsku, red. S. Rzepczyński, Słupsk 1995. 
z myśleniem o przeszłości) nie mieści się - chyba - w żadnym XIX-wiecznym kanonie myślowym. Choć z drugiej strony, przeszłość i związane z nią cierpienie są tutaj dziełem szatana, tego „co prawa rwie", a wprowadzenie postaci Złego w obręb refleksji historiozoficznej jest motywem bardzo rozpowszechnionym w romantyzmie polskim. Wystarczy tu przywołać choćby kontekst Kordiana czy Irydiona. Dziwić może jedynie, że Norwid mógłby się przychylać do tej wersji historiozoficznej, w żaden sposób niemieszczącej się przecież w obrębie chrześcijańskiego myślenia o historii. Dzieje ludzkie nie mogą być domeną diabła, ponieważ twierdzenie takie z gruntu pozostaje w sprzeczności z eschatologią katolicką. Jednak w kolejnych wersach poeta cieniuje nieco początkową, mocno kontrowersyjną tezę, wprowadzając subtelne rozróżnienie między przeszłością, a dotyczącymi jej wspomnieniami. W tym kontekście można zaryzykować tezę, że pierwsza strofa czytanego wiersza dotyczy już nie tyle obiektywnego zjawiska przeszłości (o ile w ogóle można mówić o obiektywizmie w wizji przeszłości historycznej), co raczej rozmaitych wyobrażeń odnoszących się do minionych wydarzeń. Pojawiająca się w zakończeniu pierwszej strofy kategoria wspomnienia mocno podkreśla subiektywizm naszego myślenia o przeszłości, zwłaszcza tej niedawnej. Dlatego też już nie cała przeszłość jako taka staje się obiektem działań szatana, ale tylko jej negatywna wizja, zabarwiona łzami i cierpieniem, jej wykrzywione wspomnienie.

Józef Fert w przypisach do wydania Vade-mecum wskazuje na list Norwida do Mariana Sokołowskiego (z lutego? 1865 r.) jako bezpośredni kontekst Norwidowej Przeszłości. Poeta porusza w nim kwestie związane ze stosunkiem do dziejów społeczeństwa XIX-wiecznego:

Zresztą, historia co do pr ze s zło śc i jest dziś na stanowisku osobnym i wyłącznym, i dziwnym - przeszłość nie jest to coś, jakieś, ale jest to obecność warunkowa, swoje zawsze mająca.

$$
[\ldots]
$$

Jam jej [Polski] nigdy nie łudził i wiem, że jest wielkie dziecko z zalanymi łzą oczyma, a przeto widzące jedynie przez łez swoich świętych i przeklę- 
tych pryzmat, widzące trojenia i siedmienia się tęcz - nigdy prawdy! (IX, 166)

Poeta zauważa tu w myśleniu swoich współczesnych na tematy historyczne jakieś dziwne oddalenie, jakby poczucie nierzeczywistości tego, co działo się ongiś. Brak odpowiednich narzędzi w warsztacie polskich historyków XIX-wiecznych do dokładnego przebadania dziedzictwa historycznego, do zdania sobie sprawy z rzeczywistej obecności dziejów wzbudza w poecie gwałtowne zdziwienie. To zawirowanie w ,optyce historycznej” motywuje Norwid niedawnymi wydarzeniami „okołopowstaniowymi”, które mocno skrzywiły sposób spojrzenia Polaków na całość dziejów. Gwałtowne, gorzkie uczucia wobec niedawno minionej przeszłości i teraźniejszości sprawiają, że Polska zaczyna przypominać Norwidowi wielkie, płaczące dziecko.

Właśnie ten sposób spojrzenia poety na swoich współczesnych doskonale pokazuje źródła warunkowego ukształtowania gramatycznego („Acz nie byłże jak dziecko”) i obrazowania poetyckiego, wypełniających drugą strofę Przeszłości. Odwołanie do prostego, codziennego doświadczenia wizualnego (wrażenie oddalania się mijanych przedmiotów) umożliwia Norwidowi bezpośrednie wskazanie na przyczyny podstawowego błędu ,mentalnego” polskiej historiografii XIX-wiecznej.

Bardzo ważne wydaje się też, że bez znajomości bezpośredniego „kontekstu Norwidowego” czy sposobu myślenia czytelników XIX wieku zastosowany przez poetę zabieg mógłby wydawać się niezrozumiały. Warto pamiętać o prawidłowości filologicznej, na którą błyskotliwie wskazuje Michaił Gasparow ${ }^{37}$, a polegającą na pewnym ,rozminięciu się" właściwych pod względem historycznym czytelników utworów literackich z ich odbiorcami późniejszymi, między wyobrażeniami autora o jego „czytelniku wirtualnym”, a odbiorcą późniejszym. Zasadę tę można odnieść m.in. do tego, że wiersz Przeszłość nie

${ }_{37}$ Michaił Gasparow, Filologia jako moralność, tłum. E. Skalińska, tłumaczenie, złożone do druku w „Tekstach Drugich”. 
został napisany ,dla nas”. Jego bezpośrednim adresatem był czytelnik współczesny poecie, a więc i dialog, immanentnie wpisany $\mathrm{w}$ ten utwór, nie był skierowany do odbiorcy z początku XXI wieku. Bez chociażby szkicowego odtworzenia ówczesnego sposobu myślenia cała wielogłosowość tego wiersza rozwiewa się bez śladu. Widzimy oczywiście - że toczy się w nim jakaś polemika, ale może nam brakować odpowiednich narzędzi do jej całościowej rekonstrukcji. W tym kontekście przestaje też być ważne, czy Norwid miał rację w swojej krytyce XIX-wiecznej historiografii czy też nie. Ważne, że wpisana w ten wiersz wielość rozmaitych postaw zapewne była doskonale wyczuwalna przez potencjalnych czytelników tego utworu.

Z drugiej strony - takie spojrzenie na wiersz mogłoby się mijać z postulatami samego Norwida. Przecież w ostatniej strofie poeta wyraźnie mówi o swoistej ciagłości dziejowej, o uniwersalnym pierwiastku, dającym się prześledzić w przeszłości. „P r zes złość - jest to d zi ś, tylko cokolwiek daléj”. Jak to dzieje się z większością aforyzmów Norwida, również i ten w potocznym rozumieniu bywa sprowadzany jedynie do ,głośnej” i niezbyt odkrywczej formułki o ciagłej aktualności historii. Jednak wydaje się, że w połączeniu z obrazowaniem zawartym w strofie poprzedniej można rozumieć tę sentencję w sposób nieco inny: to nie sama przeszłość oddala się od ludzi („dąb ucieka w lasu głąb”), ale ludzie coraz szybciej oddalając się o tego, co było, tracą właściwą perspektywę dziejową. Przeszłość była tworzona przez ludzi w sposób bezpośrednio analogiczny do tego, w jaki jest kształtowana ich teraźniejszość. Wiersz ten - choć na pozór zupełnie pozbawiony narodowych odniesień - w rzeczywistości jest absolutnie zakorzeniony w ,polskiej magmie dziejowej”. W tym świetle można go odczytywać już nie tyle jako nieco dziwną instrukcję dla XIX-wiecznego historiografa, co raczej jako wskazówkę skierowaną do współczesnych poecie, dotyczącą ich roli w kształtowaniu codziennej polskiej rzeczywistości.

Warto zwrócić uwagę także na to, że w tym krótkim utworze zawarte są w zasadzie dwie zupełnie odmienne wizje przeszłości. Pierwsza 
z nich, objęta ,pryzmatem łez”, jest wynikiem działania tego, ,co prawa rwie”. Ta ,przeszłość" nie jest też zbyt oddalona w czasie, swoim zasięgiem obejmują ją wspomnienia żyjących, dlatego też tak łatwo jest o zmącenie jej wizji. Druga ,przeszłość” jest już zjawiskiem bardziej zamierzchłym, przywołującym na zasadzie skojarzeniowej wizję rozmowy dowolnie rozumianej współczesności i przeszłości, w której też ,bywali ludzie”.

W ten sposób w obrębie poetyki wielogłosowości powstaje pod piórem Norwida refleksja na temat Boga i przeszłości. Nieco podobną płaszczyznę polifonicznego zobrazowania ludowej tradycji religijnej można zaobserwować również w twórczości Dostojewskiego.

Rosyjski historyk literatury, Alfred Bem, pisał w 1934 na temat Legendy o cebulce, wchodzącej w skład Braci Karamazow. Legendę tę opowiada w powieści Gruszeńka:

„Była sobie kiedyś jedna zła baba, no i umarła. I nie zostało po niej ani jednego dobrego uczynku. Chwycili ją diabli i rzucili do ognistego jeziora. Zaś anioł stróż stoi i medytuje: «Jaki by tu znaleźć jej dobry uczynek, by Panu Bogu powiedzieć.» Naraz przypomniał sobie i rzekł do Pana Boga: «Ona, powiada, z warzywniaka cebulkę wyrwała i dała żebraczce.» I odpowiedział Pan Bóg: «Weź, mówi, tę cebulkę, wsadź do jeziora, niech się baba za cebulkę chwyci, a ty ją pociągnij; jeżeli ją wyciągniesz z tego jeziora, to niech sobie do raju idzie, jeżeli się cebulka oberwie, to niech zostanie tam, gdzie jest.» Pobiegł anioł do baby, podał jej cebulkę: «Naści, powiada, babo, złap się i trzymaj.» I począł ją ostrożnie wyciagać; już, już miał ją wyciągnąć, gdy inni grzesznicy w jeziorze, zobaczywszy, że ją wyciągają, dalejże czepiać się jej, aby razem z nią się wydostać. A baba była bardzo zła, bardzo zła i zaczęła nogami wierzgać. «Mnie wyciaga, nie was; moja cebulka, nie wasza.» Ledwo to powiedziała, cebulka się urwała. I wpadła baba do jeziora i gore po dziś dzień. A anioł zapłakał i odszedł"38.

Bem zwraca uwagę na zasadnicze miejsce cytowanego utworu w strukturze powieści i na znaczną reinterpretację, której poddaje go Dostojewski. Według badacza tradycyjne rozumienie legendy, zamie-

38 Fiodor Dostojewski, Bracia Karamazow, dz. cyt., t. 2, s. 35. 
nionej pod piórem pisarza w rodzaj paraboli, zostaje w Braciach Karamazow znacząco rozszerzone. Właściwie każdy z bohaterów, występujących w rozdziale Cebulka jest obdarzony metaforyczną szansą na wyjście z piekła, rozumianego jako brak obecności Bożego Światła, jednak ostatecznie tę szansę wykorzystuje jedynie Alosza Karamazow $^{39}$.

Gdyby zaufać na słowo samemu pisarzowi, okazałoby się, że jedyną dostępną redakcją tej opowieści ludowej jest wersja przez niego zanotowana $^{40}$, a fakt ten siłą rzeczy uniemożliwiłby przyjrzenie się relacji dialogowej, która łączy ludowy przekaz legendy z jego opracowaniem literackim, dokonanym przez autora Braci Karamazow. Wiadomo jednak skądinąd, że po praz pierwszy opowieść folklorystyczna o bardzo zbliżonej fabule została opublikowana w 1859 roku przez Aleksandra Afanasjewa ${ }^{41}$ i opatrzona tytułem Brat Chrystusa ${ }^{42}$. Nie można, oczywiście, z całą pewnością zakwestionować dobrej woli Dostojewskiego, inforumującego swojego wydawcę o swoistym odkryciu folklorystycznym, jednak - jak zwraca na to uwagę Łotman - przyczyny wprowadzonej przez pisarza nieścisłości mogły mieć kilka rozmaitych źródeł, w tym chęć odżegnania się od kłopotów z cenzurą, które stały się udziałem pierwszej edycji Legend Afanasjewa ${ }^{43}$.

Dla mnie jednak najbardziej interesująca pozostaje relacja, łącząca Legendę o cebulce w artystycznym opracowaniu Dostojewskiego z jej odnotowanym pierwowzorem ludowym, który można zaprezentować w schematycznym streszczeniu:

39 Zob. Alfred Bem, Liegienda o tukowkie u Dostojewskago. (Izwlieczienije iż dokłada, proczitannogo na Mieżdunarodnom sjezdie sławistow w Warszawie, „Miecz” 1934, nr 23, s. 4.

40 Por. „Wielce szanowny Mikołaju Aleksiejewiczu, bardzo proszę o dokładną korektę legendy o cebulce. Jest to perła. Opowiedziała mi ją pewna chłopka. Zdaje się, że zapisałem ją po raz pierwszy. W każdym razie nigdy jej jeszcze nie słyszałem.” (Fiodor Dostojewski, List do Mikołaja Lubimowa. Stara Rusa, 16 września 1879 roku, w: tenże, Listy, przełożyli i komentarz opracowali Z. Podgórzec, R. Przybylski, Warszawa 1979, s. 557).

${ }_{41}$ Zob. Fiodor M. Dostojewskij, Polnoje sobranije socziniejnij $w$ tridcati tomach, t. 30, k. 1, Pis'ma 1878-1881, red. N. F. Budanowa, G. M. Frindler, I. D. Jakubowicz, Moskwa 1988, s. 316.

42 Zob. Narodnyje russkije liegiendy sobrannyje Afanassjewym, London 1859, s. 30.

43 Por. Jurij M. Łotman, Romany Dostojewskogo i russkaja liegienda, w: tenże, Riealizm russkoj litieratury 60-ch godow XIX wieka, Leningrad 1974, s. 258. 
1. Umierający starzec nakazuje swojemu synowi, żeby zawsze miał w opiece żebraków.

2. Syn postanawia w trackie Wielkanocy obdarować w cerkwi wszystkich ubogich pisankami. To zachowanie wywołuje niezadowolenie ze strony jego skappej matki.

3. Synowi zabrakło jajka dla najbardziej ubogiego żebraka. Dlatego zaprosił go do swojego domu na świąteczne śniadanie. Matka znowu sprzeciwiła się zachowaniu syna i nie wzięła udziału w poczęstunku.

4. Syn zauważa, że żebrak jest cały w łachmanach, ale ma na sobie piękny, drogi krzyż. Żebrak proponuje synowi zamianę na krzyże, ale syn początkowo się wzbrania, thumacząc się tym, że żebraka już nie będzie stać na taki drogi krzyż.

5. Żebrak dopina swego i zaprasza syna do siebie we wtorek wielkanocny. Udziela mu też konkretnej wskazówki: młodzieniec ma podążać wskazaną przezeń ścieżką z modlitwą: „Pobłogosław, Boże”.

6. Młodzieniec wyrusza we wskazanym terminie w odwiedziny do żebraka i po drodze zauważa kilka grup ludzi:

a) dzieci, pytające go, jak długo jeszcze będzie trwała ich męka;

b) panny bez ustanku przelewające wodę z jednej studni do drugiej;

c) starców $\mathrm{z}$ wielkim trudem podpierających płot.

7. Na końcu drogi młodzieniec spotyka dawnego żebraka i rozpoznaje w nim Jezusa Chrystusa. Pyta go o przyczynę męczarni spotkanych osób. Chrystus udziela mu następujących odpowiedzi:

a) dzieci męczą się, ponieważ jeszcze w zarodku zostały przeklęte przez własne matki;

b) panny pokutują, ponieważ za życia rozcieńczały sprzedawane mleko woda;

c) starcy ponoszą karę za to, że za życia twierdzili, że wolą dobrze pożyć na świecie doczesnym, a po śmierci mogą przez całą wieczność podpierać płot.

8. Chrystus oprowadza młodzieńca po raju: pokazuje mu miejsce, przygotowane specjalnie dla niego. Następnie prowadzi go do piekła i wskazuje na matkę młodzieńca, tkwiącą w gotującej się siarce. 
9. Młodzieniec prosi Chrystusa o wybaczenie jej grzechów. Chrystus zgadza się pod warunkiem, że młodzieniec skręci sznur z łodyg, za pomocą którego wyciagnie matkę.

10. Młodzieniec skręca sznur, wrzuca go do wrzącej siarki i zaczyna wyciagać matkę. Kiedy już udaje mu się chwycić ją za głowę, matka, zarzuca mu, że próbuje ją udusić. Sznur pęka, a matka stacza się z powrotem do kipieli.

11. Chrystus mówi, że matka nie była w stanie nawet teraz powstrzymać złych odruchów swego serca, dlatego już na zawsze zostanie w piekle.

Widać wyraźnie, że Dostojewski wykorzystuje w swojej Legendzie o cebulce jedynie ostatnią część opowieści ludowej. Tylko ona wydała się pisarzowi konieczna do wzmocnienia artystycznej całości, ukazującej kroczenie Aloszy nad otchłanią grzechu i upadku. Jednak i tu dokonuje pisarz znaczącej reinterpretacji przekazu ludowego, Aloszy udaje się wybrnąć z duchowego piekła dzięki podanej mu przez Gruszeńkę-anioła cebulce. Z drugiej strony również zachowanie Gruszeńki zyskuje dwa wymiary: jest ona jednocześnie ofiarodawczynią tej specyficznie rozumianej jałmużny duchowej i jej adresatką. Przecież również Alosza, dziękując jej i mówiąc o tym, że jest dobra, podaje jej „cebulkę”, która może uratować ją przed piekłem spotkania z dawnym kochankiem. Gruszeńka jednak nie wytrzymuje i podana jej cebulka „pęka”. Bohaterka udaje się na spotkanie z ,uwodzicielskim Polakiem".

W ten sposób finalna część ludowej przypowieści o Bracie Chrystusa zostaje przez Dostojewskiego poniekąd zwielokrotniona: pod schematyczne postaci matki i syna zostają przezeń podłożone przeplatające się głosy wielu bohaterów, dążących do zbawienia siebie i udzielenia duchowej pomocy Innemu.

Jednak na tym nie kończy się wpływ, jaki wywarła lektura Brata Chrystusa na autora Braci Karamazow. W przywoływanym wcześniej tekście Łotman zwraca uwagę na szczególny gest zamiany krzyży 
w Idiocie, przyjęty przez Dostojewskiego najprawdopodobniej właśnie z omawianego tekstu folklorystycznego. Jednocześnie badacz zdaje się zupełnie ignorować pytania moralno-eschatologiczne, występujące zarówno we wskazanym przekazie ludowym, jak i w Braciach Karamazow. Chodzi oczywiście o pytania, przed którymi staje Młodzieniec w trakcie wędrówki do domu swojego gościa-żebraka. Najpewniej szczególnie niepokojące wydało się Dostojewskiemu jedno z nich - pytanie o sens cierpienia niewinnych dzieci, o ich cierpienie nie tylko w rzeczywistości doczesnej, ale też w życiu pozagrobowym. Charakterystyczne, że o ile kara, jaka spotkała Panny i Starców została w przypowieści ludowej dokładnie opisana, o tyle rodzaj cierpienia, któremu poddano dzieci, nie został przez ludowego narratora w żaden sposób dookreślony. Odpowiedź, jakiej udziela Chrystus Młodzieńcowi (dzieci cierpią, ponieważ zostały przeklęte przez własne matki) wywołuje oczywisty sprzeciw moralny zarówno wśród dzisiejszych czytelników legendy, jak zapewne i wśród wykształconych warstw jej odbiorców XIX-wiecznych. Można się domyślać, że tego rodzaju sprzeciw wobec niezawinionego cierpienia dziecięcego został przez Dostojewskiego dokładnie wyeksplikowany w rozmowie Iwana z Alo$\mathrm{sza}^{44}$. Zresztą wykorzystany przez Iwana argument o niezawinionym cierpieniu dziecięcym stał się tym, który najmocniej oddziałał na wyobraźnię Aloszy i zachwiał jego wiarą w dobro Boga Stwórcy.

Podania folklorystyczne były dla Dostojewskiego jednym z najważniejszych źródeł poznawania ludowej mentalności prawosławnej. Wart podkreślenia jest fakt, że mimo całej fascynacji religijnością ludową, pisarz przygląda się przesłaniu zawartemu w ruskim folklorze prawosławnym ze znaczącym dystansem. Chyba żadne z wykorzystanych przez niego podań ludowych nie zostało potraktowane przezeń zupełnie bezkrytycznie. Jak pisze Łotman:

[...] proces twórczego przyswajania przez Dostojewskiego problematyki artystycznych właściwości legendy miał charakter skomplikowany

44 Por. Bracia Karamazow, dz. cyt., t. 1, s. 272-293. 
i sprzeczny w sobie: Dostojewski nierzadko polemizował z tradycją folklorystyczną, czasem w sposób bardzo swoisty nadawał jej nowy sens, ale na zawsze włączył legendy w krąg zjawisk literackich, które „brał pod uwagę", wnikając w ludowe wyobrażenia etyczne. Przy tym materiały folklorystyczne i teksty staroruskie łączyły się w jego świadomości ze współczesnością, jej zainteresowaniami i problemami codziennymi. Legenda nie stała się po prostu źródłem obrazów i wątków fabularnych jego powieści, lecz jednym z impulsów twórczych, pobudzających myśl pisarza. Została ,sprzężona” w jego wyobraźni z innymi wrażeniami, z innymi ,akumulatorami” idei artystycznych ${ }^{45}$.

\section{$*$}

Przywołane wyżej przykłady ,polifonii strukturalnej”, zauważalnej zarówno w twórczości Norwida, jak i Dostojewskiego mają - oczywiście - charakter zgoła odmienny. Wielogłosowy wiersz Norwida, odwołujący się do współczesnego mu braku ,instynktu historycznego" i fragment powieści Dostojewskiego, podejmujący dialog ze współczesną mu religijną wyobraźnią ludową - zasadniczo - nie dają się porównywać. Niemniej podstawowym elementem, który je łączy, jest aż nadto wyraźna próba obu twórców podjęcia dialogu z własną epoką i z jej najważniejszym elementem - tradycją. Chociaż znaczenie obu analizowanych wyżej tekstów jest zupełnie odmienne, łączy je niewątpliwie wola wprowadzenie w obręb własnego tekstu fragmentów „mowy ikonicznej” Innego i próba nawiązania z nim dialogu.

\section{Dialog niemożliwy}

Michaił Bachtin w następujący sposób przedstawia istotę dialogu w powieściach Dostojewskiego:

Samoświadomość bohatera Dostojewskiego jest na wskroś zdialogizowana: zawsze kieruje się na zewnątrz, w napięciu zwraca się do siebie, do drugiego, do trzeciego. Również dla siebie samej nie istnieje inaczej niż

45 Jurij Łotman, Romany Dostojewskogo..., dz. cyt., s. 283. Tłum. moje - E. S. 
w tym żywotnym nakierowaniu na siebie i innych. W tym sensie człowieka Dostojewskiego można określić jako p od mi ot zw ra c a ni a si ę. Nie wolno mówić o nim, można jedynie zwracać się do niego ${ }^{46}$.

Z całą pewnością można sądzić, że podobną funkcję pełni dialog również w twórczości Norwida, a zwłaszcza w jego poezji lirycznej. Ciekawa grupa przykładów, szczególnie jaskrawo pokazujących tę tendencję dialogiczną polskiego poety są jego tzw. wiersze miłosne. Liryki Norwida, nawiązujące do szeroko rozumianej tematyki erotycznej, dotychczas bywały analizowane raczej rzadko $^{47}$. Warto jednak zwrócić uwagę, że właśnie tu chyba w sposób najbardziej wyraźny uwidacznia się dążenie podmiotu lirycznego (i być może zarazem również podmiotu autorskiego) do nawiązania pełnej, całościowej więzi komunikacyjnej z Innym.

Niebagatelne znaczenie ma tu zjawisko, na które zwraca uwage Barbara Stelmaszczyk: w liryce miłosno-salonowej Norwida zwykle nie dochodzi do rzeczywistego porozumienia między podmiotem mówiącym a jego interlokutorką ${ }^{48}$. Pragnienie nawiązania tego rodzaju rzeczywistego, spełnionego dialogu wyraźnie przebija przez takie wiersze jak: Marionetki, Jak..., Trzy strofki, Czemu, [Pierwszy list, co mnie doszedł z Europy...], Beatrix, Malarz z konieczności lub też [Co? jej powiedzieć...]. Zwłaszcza ostatni z wymienionych liryków może być rozpatrywany jako czołowy przykład braku porozumienia między „niewiastą zaklętą w umarłe formuły” a podmiotem lirycznym.

46 Michał Bachtin, Problemy twórczości Dostojewskiego, dz. cyt., s. 282.

$47 \mathrm{Z}$ tekstów najnowszych, pozostających w kręgu zainteresowania wierszami miłosnymi Norwida należy wymienić przede wszystkim dwa szkice: artykuł Dariusza Seweryna, poruszający zagadnienie ,wyobraźni erotycznej Norwida” (Dariusz Seweryn, ,,Śpiqc z Epopeja”. O możliwości badania wyobraźni erotycznej Norwida, w: Jak czytać Norwida? Postawy badawcze, metody, weryfikacje, red. B. Kuczera-Chachulska, J. Trzcionka, Warszawa 2008) oraz szkic Barbary Stelmaszczyk, poświęcony sposobom autoprezentacji podmiotu lirycznego wobec kobiety w wybranych wierszach Norwida (Barbara Stelmaszczyk, Autoportret z kobieta $w$ tle. O liryce Norwida, w: Rozjaśnianie ciemności. Studia i szkice o Norwidzie, red. J. Brzozowski, B. Stelmaszczyk, Kraków 2002).

48 Barbara Stelmaszczyk, dz. cyt., s. 62-63. 
1

Co? jej powiedzieć... ach! co się podoba,

Bez rozmawiania sposobu;

Coś - z prawd ogólnych: na przykład, że doba

To - całego obrót globu!

2

Że świat... obiega mil mnóstwo ogromne

Na jedno pulsu zadrżenie -

Bieguny osi skrzypią wiekopomne:

Czas - niepokoi przestrzenie - -

3

Że rok... to - całej wstrząśnienie przyrody,

Że pory-roku... nie tylko

Są zamarzaniem i tajeniem wody,

I - że - - bicie serca?... c hwilką !

4

To - jej powiedzieć...

Gdzie jest zimniej? gdzie goręcej?

...i przejść do pogody,

I dodać - jakie? są na ten rok Mody...

I nic nie powiedzieć więcej.

(II, 190-191)

Wspomniana przed chwilą badaczka (Stelmaszczyk), komentując przytoczony wyżej wiersz, pisze: ,Tu, aby zaistnieć, bohater musi poruszać się po orbicie ogólników i banalnych stwierdzeń: pseudoodkrywczych i pozornie głębokich, ponad które nie może powiedzieć nic więcej" ${ }^{49}$. Trudno jest w pełni zgodzić się z przytoczonym wyżej sądem, zwłaszcza mając w pamięci Norwidową formułę, pochodzącą z Moralności - „kochający koniecznie bywa artystą”. Właśnie uczucie miłości, głęboko wpisane w strukturę emocjonalną interpretowanego liryku, sprawia, że układany przez podmiot wiersza dialog, dialog, któ-

49 Tamże, s. 66. 
ry (jak możemy się domyślać) nie zostanie nigdy właściwie rozwinięty, jest tak bardzo liryczny. Oczywiście, poruszane przez mówiącego zagadnienia astronomiczno-przyrodnicze niekoniecznie muszą być uznane za odkrywcze. Jednak kierowane (nawet - potencjalnie) do osoby kochanej stają się choćby ułamkowym pretekstem do mówienia o własnych uczuciach i zarazem pełnią funkcję fatyczną.

Pierwsza strofa rzeczywiście pozostaje w obrębie ironicznego dystansu, tworzonego przez podmiot liryczny. Ważna tu jest i sama refleksja nad przyszłą sytuacją komunikacyjna, (przecież tego rodzaju „projektowanie” biegu rozmowy nie należy do czynności zbyt powszechnych i neutralnych pod względem psychicznym); i ironiczne stwierdzenie: „co się podoba”, pod którym ukrywa się dramat miłości niewypowiedzianej wprost; i egzemplifikacja ,prawdy ogólnej”. Mimo tych wszystkich potencjalnych zastrzeżeń już od początku drugiej strofy widocznie zmienia się sposób modelowania wypowiedzi podmiotu lirycznego. Chłodny ironiczny dystans jest tu stopniowo wypierany przez liryczne serio. Okazuje się, że również „,prawdy ogólne” moga stać się - w pewnych warunkach - zupełnie niezwykłe.

Ukazana w drugiej strofie paralela między rozmachem pędzącej kuli ziemskiej a jednym delikatnym, jakby nieśmiałym uderzeniem serca (,„pulsu zadrżeniem”) wprowadza czytelnika w obręb nowoczesnego, modernistycznego obrazowania poetyckiego. Ten ,szczegół liryczny” może przywodzić na myśl pewien fragment Listów poetyckich z Egiptu Słowackiego: „Słyszę zegarek bijący i serce. Czas i życie”. To właśnie tym wersem tak bardzo zachwycał się Białoszewski, upatrując w nim przeczucia zwięzłości i oszczędności poezji lingwistycznej ${ }^{50}$. Pojawiające się u Norwida zestawienie nieśmiałej, może nie do końca świadomej samej siebie emocji, z rozmachem pędu kosmicznego zdaje się znajdować właśnie w tym samym nurcie obrazowania poetyckiego, co znacznie późniejsza poezja eksperymentalna. Żeby nie dostrzec podwójności tego sposobu mówienia, nie wyczuć delikatnie zakamuflo-

50 Zob. na ten temat: Jan Zieliński, Słowacki. SzatAnioł, wyd. II, Warszawa 2009, s. 237. 
wanych w nim treści emocjonalnych, trzeba być naprawdę ślepym i głuchym.

Kolejna „pseudoodkrywcza” (zdaniem Stelmaszczyk) informacja fizyczno-astronomiczna pojawia się w następnych wersach:

Bieguny osi skrzypią wiekopomne:

Czas - niepokoi przestrzenie - -

Tutaj z (rzecz jasna z przymrużeniem oka) można by rzec, że poeta wprowadza nas na teren fizyki eksperymentalnej. Naturalnie, rozmaite wariacje na temat czasu są stałym motywem literackim już od starożytności, natomiast niewątpliwym novum staje się tutaj połączenie dwóch elementów fizykalnych: czasu i przestrzeni ${ }^{51}$, które przecież jest wynalazkiem stricte XX-wiecznym. Na płaszczyźnie dialogowego obrazowania lirycznego istotne staje się zestawienie elementu tradycji (ciągłości, trwania czy też „pamięci dziejowej”, wpisanej w każdy atom globu ziemskiego) z pędzącym czasem, wyrywającym świat z zadumy, niepokojącym go swoimi zmianami. W ujęciu metaforycznym czas jakby „wdziera się” w trwającą przestrzeń, wprowadza do niej ko-

51 To zestawienie „czasoprzestrzenne” pojawiło się u Norwida (przynajmniej raz) już wcześniej w przedziwnym wierszu, wchodzącym w obręb noweli Cywilizacja:

„Pożegnałem, co kochałem,

Upominek złączy nas;

Ręką jedną - przestrzeń dałem,

Drugą ręką dałem c z a s."

(VI, 45)

Zreszta, wypada w tym miejscu zaznaczyć, że Bachtin rozszerzył rozumienie kategorii czasoprzestrzennych (tzw. chronotopu) na całość dziejów literatury pięknej i analizował immanentną obecność czasoprzestrzeni na przykładzie powieści antycznych (zob. Michał Bachtin, Czas i przestrzeń w powieści, „Pamiętnik Literacki”, LXV, 1974, z. 4, tłum. J. Faryno, s. 273-311). W moim odczuciu, nie zmienia to jednak faktu, że bezpośrednie zestawianie ze sobą pojęcia czasu i przestrzeni, dopatrywania się w nich nierozdzielnej całości nie było w literaturze XIX-wiecznej wcale takie oczywiste. Na temat kategorii czasu i przestrzeni w literaturze zob. np. Georges Poulet, Metamorfozy czasu, tłum. W. Błońska, Warszawa 1977. Czas i przestrzeń w prozie polskiej XIX i XX wieku, red. Cz. Niedzielski, J. Speina, Toruń 1990. Przestrzeń i literatura. Studia, M. Głowiński, A. Okopień-Sławińska, Wrocław 1978. Tadeusz Sławek, Wnętrze. Z problemów doświadczenia przestrzeni w poezji, Katowice 1984. 
nieczność ruchu i zmiany. A mając w pamięci podstawowe motywy twórczości Norwida, chciałoby się dodać - zmiany cywilizacyjnej.

Warto pamiętać, że cała ta obszerna problematyka filozoficzno-przyrodnicza funkcjonuje jako immanentny składnik dialogowego liryku miłosnego. To obrazowanie, nawiązujące wprost do dziedziny nauk ścisłych, jest bezpośrednim odwołaniem i do „kosmogonii” Dantego, poszukującego swojej Beatrycze, i do metafizycznej poezji barokowej. Tak więc, wypełniający zasadniczą część wiersza „wywód przyrodniczy", staje się w tym kontekście kunsztownym nawiązaniem do najlepszych tradycji europejskiej liryki miłosnej. Jednocześnie bogactwo nawiązań dialogowych (z których - zapewne - został wskazany jedynie ułamek) sprawia, że wiersz ten może się okazać nie do końca czytelny. Jego struktura intertekstualna rzeczywiście mogła być dla czytelnika XIX-wiecznego, nieoswojonego z tym sposobem pisania, nie do końca jasna.

Pod koniec trzeciej strofy bezpośrednio powraca motyw „,bicia serca". Jest on ponownie usytuowany przez podmiot mówiący w kontekście chwilowości. Jednak nie jest to chwilowość wiążąca się z przemijalnością, ale raczej - z tą wyjątkową chwilą, w której może dojść do rzadkiego momentu pełnego porozumienia, rzeczywistego spotkania dwojga ludzi. Chyba tylko wtedy, w takiej szczególnej chwili, może zaistnieć „dialog nieupozorowany”. Zatem całość wiersza może być odczytywana jako próba stworzenia „planu” takiej pozornie niewiele znaczącej konwersacji, w której może dojść do pełnowymiarowego spotkania. Jednocześnie od początku widać wyraźnie, że jest to rodzaj próby desperackiej, z góry skazanej na niepowodzenie. Rozpoczynający ostatnią strofę, urwany w połowie wers: „To jej powiedzieć...” staje się (również graficznym) sygnałem przeczuwanej, nieuchronnej klęski dialogowej. Zgodnie z przytoczoną wcześniej „personalizującą” koncepcją Bachtinowska, podmiot liryczny właśnie zw ra ca s i ę do ukochanej, mówi do ni j. Jednak ta propozycja dialogu pozostaje bez odpowiedzi. Klauzulowa kompozycja wiersza („Co? jej powiedzieć... [...]/ I nic nie powiedzieć więcej”) pokazuje wprost, że plano- 
wana rozmowa będzie ostatnią próbą sprowokowania dialogu, dialogu - w tej sytuacji - poniekąd niemożliwego.

Dodatkową przyczyną niemożliwości nawiązania prawdziwego, głębokiego dialogu między podmiotem lirycznym i adresatką jego wypowiedzi jest - zupełnie oczywista w przypadku twórczości Norwida - bariera grzeczności salonowej. Liryki i nowele autora Bransoletki są swoistą kopalnią antywzorców rozmów prowadzonych „,na salonach”. Do najbardziej znanych pod tym względem utworów Norwida należą: Stygmat, Bransoletka, Assunta, Ostatni despotyzm, Nerwy, Marionetki, fragmenty Aktora i Pierścienia Wielkiej Damy. Na przykład, dobrze opisaną w literaturze przedmiotu Norwidową koncepcję ,stygmatu salonowego" można by skomentować w sposób następujący:

Porządek socjologiczny zakłada sztuczność [mowy - E. S.]. W jego skład wchodzą i struktury społeczne, i tworzone przez wieki teorie, doktryny i systemy - filozoficzne, religijne lub polityczne. Każdy z nich posiada własny język, którego rozwój sprzyja rozwojowi doktryny. Teorie, nauczanie, doktryny są obdarzone własną dynamiką niezależną od woli ludzi, ich twórców, którzy stają się ich ofiarami. Język doktryny czasem jest potężniejszy od jej sensu: forma językowa bierze górę nad zawartością myślową. Tak przychodzi na świat I d e a - właśnie ta despotyczna Idea, która swoim językowo-logicznym nieprzepraciem podporządkowuje sobie człowieka ${ }^{52}$.

Powyższy cytat pochodzi z rozprawy rosyjskiego badacza, Jefima Etkinda, poświęconej m. in. twórczości Fiodora Dostojewskiego. Etkind, wysuwając tezę o niemożliwości pełnego wypowiedzenia przez bohaterów pisarza rosyjskiego ich ,głębin duchowych”, ilustruje ją dwoma przykładami: Raskolnikowa i Myszkina. W tej chwili najbardziej interesujący wydaje się drugi z wymienionych przykładów, zwłaszcza, że badacz wiąże go z socjologizującą analizą,,społeczności salonowej” i nieprzystawalnością do niej Myszkina. Ważny wydaje się

52 Jefim. G. Etkind, Wnutriennij cziełowiek i wnieszniaja riecz'. Oczierki psichopoetiki russkoj litieratury XVII-XIX wiekow, Moskwa 1998, s. 268. Tłum. moje - E. S. 
fakt, że tytułowy bohater - od samego początku powieści nieposiadający ustalonego statusu społecznego - nie potrafi z reguły odnaleźć się w sposób właściwy w rozmowach wymagających znajomości społecznych ,reguł mówienia” (np. w trakcie oświadczyn w salonie Nastasji Filipowny czy też przy okazji pierwszej rozmowy z ,synem Pawliszczewa”). Etkind motywuje tę specyficzną cechę Myszkina faktem, że książę, w pełni szanując każdego swego rozmówcę, chce pozostawać wobec niego absolutnie, krystalicznie uczciwy. Zaś w pełni uczciwe i szczere formułowanie swoich najgłębszych myśli musi przychodzić z pewną trudnością i z reguły zostaje okupione czymś, co w myśl światowych konwencji XIX-wiecznych bywało określane mianem „naiwności” czy „niezrozumiałości”. Z kolei kłamstwo, w jego najszerszym rozumieniu i etycznym, i filozoficznym

[...] nie sprawia mówiącemu trudności. Trudność językowego wcielenia prawdy jest wywołana koniecznością przejścia od stanu duchowego, od czasem nieokreślonego odczucia czy skomplikowanych i sprzecznych myśli, do ujęcia go w mniej lub bardziej wyraźnych słowach. Słowa powinny odpowiadać swojemu powołaniu - być pełnowartościowym zewnętrznym wcieleniem świata wewnętrznego, materializacją procesów duchowych. Mówiąc w sposób obrazowy, przekład na język słów musi być zgodny z oryginałem. Zaś w przypadku kłamstwa - oryginału nie ma. Kształt językowy nie podlega żadnym wymaganiom wierności lub precyzji. [...] Kłamstwo to imitacja przekładu z języka duchowego na język materialny, jego falsyfikat ${ }^{53}$.

Ponieważ prawie żaden z bohaterów Idioty (może poza kilkoma postaciami, w tym Agłają Jepanczyn) nie potrafi w pełni przestawić się z konwencjonalnego kodu językowego, opierającego się na specyficznie rozumianym kłamstwie, na język bezpośredni i „naiwny” (język, którym mówi Lew Myszkin) pełny, właściwy dialog, nie może zaistnieć na kartach tej powieści. (Podobnie jak to się czasem dzieje w twórczości Norwida).

53 Tamże, s. 239. Thum. moje - E. S. 
Rzecz jasna, przedstawiony wyżej problem nie ogranicza się w twórczości Dostojewskiego wyłącznie do Zbrodni i kary czy Idioty. To samo założenie twórcze możemy odnaleźć - w formie odwróconej - na przykład w monologowej części Notatek z podziemia. Ich główny bohater i narrator zdradza na początku pragnienie zupełnego wypowiedzenia się przed całym światem, który dotychczas jedynie obserwował ze swojego „podziemia”. Taka postawa zwykle wiąże się z chęcią nawiązania rzeczywistego dialogu, jednak w tym przypadku jest to dialog z założenia pozorny, wynikający z chęci opisania siebie samego w jak najgorszym świetle po to, żeby chociaż w taki sposób zwrócić na siebie uwagę. Można to określić mianem strategii permanentnego kłamcy, nawiązującej w znacznym stopniu m. in. do zachowania Lebiediewa względem Myszkina. Narrator Notatek nieustannie polemizuje z domniemanym słuchaczem. Usiłując - pozornie - nie dopuścić do najmniejszego nieporozumienia, ciagle dopowiada szczegóły do swoich negatywnych cech i stanów psychicznych, okraszając swoją ,,apologię" udawaną wesołością.

Jestem człowiekiem chorym... Człowiekiem zły m. Niepociagającym. Myślę, że cierpię na wątrobę. Nie mam zresztą zielonego pojęcia o mojej chorobie i nie wiem na pewno, co mi dolega. Nie leczę się i nigdy się nie leczyłem, chociaż szanuję medycynę i lekarzy. W dodatku jestem niezwykle przesądny; no, w każdym razie na tyle, żeby ocenić medycynę. (Posiadam dostateczne wykształcenie, aby nie być przesądnym, ale jestem.) Nie, ja się nie chcę leczyć - n a zło ść. Cóż, państwo z pewnością tego nie pojmujecie. A ja pojmuję. Oczywiście, nie potrafię wam wythumaczyć, komu w tym wypadku dopiekę swoją z ł o ś c i ą; wiem doskonale, że doktorom w żaden sposób nie zdołam ,przysolić” tym, że się u nich nie kuruję; wiem lepiej od kogokolwiek, że tym wszystkim zaszkodzę tylko sobie i nikomu więcej. A jednak jeśli nie leczę się - to właśnie n a złość . Wątróbka boli, no to niech boli jeszcze bardziej ${ }^{54}$ !

W przytoczonym wyżej, inicjalnym fragmencie Notatek czterokrotnie w różnych konfiguracjach pojawia się określenie ,złość”. Właśnie

54 Fiodor Dostojewski, Notatki z podziemia. Opowieść, tłum. G. Karski, w: tenże, Gracz. Opowiadania 1862-1869, Warszawa 1964, s. 56. Podkr. moje - E. S. 
ta emocja wysuwa się na czoło pierwszej części opowiadania. Jednak to uczucie jest kierowane przed narratora niemalże w tym samym stopniu do swojego domniemanego słuchacza-oponenta, co do siebie samego. „Jestem człowiekiem złym”, mówi na początku ,„paradoksalista z podziemia" i dlatego wszystko, co robię wobec siebie samego i innych, robię właśnie „,na złość”. Ciekawe, że na początku siła destrukcyjna tego uczucia jest kierowana przede wszystkim wobec samego mówiącego. Jego złość na samego siebie wywołuje nawet to, że nie potrafił tak naprawdę stać się człowiekiem złym ${ }^{55}$.

Jedyny rzeczywiście dokładnie opisany przykład złego, nagannego pod względem etycznym postępowania został przedstawiony przez narratora w drugiej części Notatek - Z powodu mokrego śniegu. Kluczową częścią tego fragmentu opowiadania jest jego dialog z prostytutką Lizą. Na płaszczyźnie samej konstrukcji dialogowej wspomniana rozmowa nie budzi żadnych zastrzeżeń, sugeruje nawet nawiązanie prawdziwego, spełnionego dialogu. Bohaterowi udaje się w odpowiedni sposób przemówić do Lizy, wywołać jej skruchę i chęć porzucenia uprawianego zawodu. Rzeczywiste intencje, wynikające jakby z rozdwojenia wewnętrznego narratora, ujawniają się jedynie we fragmentach komentujących jego własne słowa, skierowane do Lizy. Okazuje się, że cała jego płomienna i nieco „kaznodziejska” przemowa była wynikiem jedynie obranej przezeń konwencji, uniemożliwiającej prawdziwe porozumienie i pozwalającej bohaterowi na zachowanie bezpiecznego dystansu wewnętrznego wobec rozmówczyni. Warto zaakcentować fakt, że ,człowiek z podziemia” ciagle balansuje na granicy prawdy i fałszu: rzeczywistej intencji pozytywnej i błazeńskiej gry:

Odwróciłem się z obrzydzeniem; nie rezonowałem już na chłodno. Sam zaczynałem odczuwać to, co mówiłem, i gorączkowałem się. Pragnąłem wyłożyć swoje umiłowane, wyhodowane w zaciszu i d e j ki. Coś się we mnie nagle zapaliło; jakiś cel się „ukazał”56.

\footnotetext{
55 Tamże, s. 57.

56 Tamże, s. 129.
} 


\section{A następnie:}

Więc i ona już jest zdolna do pewnych refleksji?... „Do licha, to ciekawe, takie po krew i eń s tw o d u chowe - pomyślałem, niemal zacierając ręce. - I jak tu nie zatriumfować nad taką młodą duszą?..."

$[\ldots]$

„Trzeba utrafić we właściwą tonację - przemknęło mi przez myśl - sentymentalnością tu niewiele chyba można wskórać."

Zresztą tak tylko przemknęło mi przez myśl. Przysięgam, że Liza naprawdę mnie interesowała. Byłem przy tym jakiś osłabły i rozstrojony. A zresztą chytrość tak łatwo godzi się z uczuciem ${ }^{57}$.

Zakończenie tej historii jest aż nadto dobrze znane. Żeby w pełni otworzyć się na Innego, trzeba najpierw stanąć w prawdzie wobec siebie samego, a to przerosło możliwości duchowe autora Notatek. Wypada może jeszcze na zakończenie tej refleksji zwrócić uwagę na odautorską adnotację, kończącą Notatki z podziemia. „Nie wytrzymał i pisał dalej" - powiada Dostojewski, a to w planie duchowym sugeruje potencjalną możliwość prawdziwego „wytłumaczenia się” Człowieka z Podziemia. W końcu, jak pisze Bachtin:

Na płaszczyźnie swojego religijno-utopijnego światopoglądu Dostojewski przenosi dialog do wieczności, pojmując ją jako wieczne współ-radowanie się, współ-zachwyt, zgodne współ-głoszenie. Na płaszczyźnie powieści wyraża się to w niemożliwości zakończenia dialogu, na początku zaś w jego złej nieskończoności ${ }^{58}$.

$*$

Bez żadnej wątpliwości można powiedzieć, że wielogłosowość poezji Norwida i polifonia powieści Dostojewskiego są zjawiskami bardzo do siebie zbliżonymi zarówno pod względem formalnym (poetyka dzieła literackiego), jak i artystycznym (estetyczny cel zjawiska). Jednocześnie nie sposób przecenić wpływu, który wywarło novum

57 Tamże, s. 130-131.

58 Michał Bachtin, Problemy twórczości Dostojewskiego, dz. cyt., s. 282. 
wprowadzone przez Dostojewskiego w obręb sposobów pisania powieści od wieku XIX poczynając, a na literaturze najnowszej kończąc. Trzeba również przyznać, że dokonane przez Norwida odkrycie wielogłosowości w poezji przez wiele lat drzemało w ukryciu, pozostawało niedostrzeżone nie tylko przez poetów, lecz również przez badaczy literatury. Jednak w ostatnim czasie pojawia się coraz więcej prac, przyczyniających się do bardziej dokładnego opisu tego wyjątkowego zjawiska w poezji polskiej. Należy do nich m.in. szkic Anny Kozłowskiej, ujmującej Norwidową wielogłosowość od strony językoznawczej:

Obfitość wtrąceń nawiasowych w Vade-mecum [...] znakomicie wpisuje się [...] w Norwidową praktykę konstruowania tekstu wielogłosowego, takiego, w którym poprzez komplikacje syntaktyczne wyraża się wielość możliwych perspektyw oglądu i oceniania zjawisk. Dokonujące się poprzez użycie nawiasów „poziomowanie składniowe wypowiedzi” służy wewnętrznej dialogiczności tekstu czy też - przywołując termin Bachtina - jego polifoniczności, rozumianej jako obecność „mnogości samodzielnych niespójnych głosów i świadomości" ${ }^{\prime 59}$.

Istotne, że wielogłosowość, polifonia czy też dialogowość (traktowane tutaj w sposób niemalże synonimiczny) realizowane w twórczości obu artystów, przejawiają się w podobny sposób. Obaj dialogują z tradycją, sugerując wprowadzenie w jej obręb pewnych zmian; obaj też manifestują prawdziwie chrześcijański szacunek wobec Innego, modelując jego głos w sposób zupełnie autonomiczny. A przede wszystkim obaj dostrzegają takie obszary prób porozumienia międzyludzkiego, w których prawdziwy dialog nie może jeszcze zaistnieć.

Rzecz jasna, nie brakuje w tym zestawieniu również odmienności. Taką cechą zasadniczo różniącą warsztaty twórcze polskiego poety i rosyjskiego prozaika jest stopień podporządkowywania naczelnej idei utworu jego strukturze polifonicznej. W przypadku powieści czy opowiadań Dostojewskiego stopień natężenia wielogłosowości potrafi

\footnotetext{
59 Anna Kozłowska, Nawiasem mówiqc. O wtrqceniach nawiasowych $w$ wierszach $z$,, Vade-mecum" Cypriana Norwida, w: Norwid. Z warsztatów norwidologów bielańskich, red. T. Korpysz, B. Kuczera-Chachulska, Warszawa 2011, s. 65.
} 
być tak wysoki, że przesłanie utworu lub też jego naczelna ,idea” zaczynają się rozmywać i nawet najbardziej fachowy czytelnik staje wobec tego ,różnogłosego-monologu” (żeby użyć określenia Norwidowego) zupełnie bezradny. Pod tym względem lektura Norwida pozostawia zupełnie inne wrażenie. Choć wielogłosowość jego utworów również jest bardzo wyraźna, to jednak zawsze można w niej wyczuć głos nadrzędny - motyw porządkujący wszystkie pozostałe głosy, doskonale je rezonujący.

\section{Abstract \\ Ewangelina Skalińska, Polyphony of Dostoyevsky's Novels and the polyphony of Norwid's poetry}

The article compares dominating strategies of writing in Norwid's and Dostoyevsky's literary output. The author presents the sources of the conversational concepts in the writings of both Norwid and Dostoyevsky. She also reflects upon the origins of the indicated affinity.

Trasl. Mateusz Falkowski 